\title{
La acción civil de extinción de dominio: el retorno al cuerpo del delito
}

The civic action of forfeiture: Return to corpus delicti

\author{
Jorge Rivero Evia ${ }^{1}$ \\ Tribunal Superior de Justicia del Estado de Yucatán, México \\ jorge.rivero@tsjyuc.gob.mx \\ http://orcid.org/0000-0002-8319-1206
}

\begin{abstract}
Resumen: La acción civil de extinción de dominio, presenta cuatro elementos para su configuración: a) la existencia de un hecho ilícito (de los enunciados en la Constitución mexicana); b) la existencia de bienes producto o que fueron utilizados para la comisión de uno de esos hechos ilícitos; c) el nexo de causalidad entre los dos primeros requisitos; y d) que el propietario de los bienes tuviera conocimiento de tales actividades antijurídicas. Ahora bien, el primer elemento (denominado el punto de conexión) será demostrado con independencia de la causa penal de origen; o sea, prescindiendo de los elementos personales como la culpabilidad del agente. Ello recuerda a la teoría (penal) del Causalismo, que entendió por el cuerpo del delito "los elementos de la descripción típica que constituyen la materialidad del hecho". Esta teoría, junto con la Finalista y la Funcionalista, han estado presentes en la normatividad penal mexicana. Hoy día, en el ámbito penal no se hace referencia expresa a ninguna de ellas; empero, ese elemento "hecho ilícito" de la acción de extinción de dominio, es exactamente compatible con el "cuerpo del delito".
\end{abstract}

Palabras clave: Extinción de dominio; Elementos de la acción; Teoría del delito; Causalismo; Cuerpo del delito; Hecho ilícito.

1 Doctor en Derecho por la Universidad Anáhuac Mayab (Mérida, México); Investigador Nivel 1 del Sistema Nacional de Investigadores del CONACYT; Magistrado Presidente de la Sala Colegiada Civil y Familiar del Tribunal Superior de Justicia del Estado de Yucatán (México). 
ABSTRACT: The civic action of forfeiture ${ }^{2}$ features four elements for its configuration: a) the existence of an illicit act (corresponding to those stated in the Mexican Constitution), b) the existence of good(s) produced by or used in committing those illicit acts, c) the causal link between the first two required elements, and d) that the owner of the good(s) is aware of said unlawful activities. That said, the first element (labeled as the connection point) will be demonstrated independently from the original criminal case; that is, regardless of personal elements such as agent culpability. This reminds of the (criminal) theory of causality, which describes the corpus delicti as "the elements of a typical description that constitute the materiality of a fact". This theory, along with the Finalist and Functionalist approaches, has been present in Mexican criminal regulations. Today, in the criminal realm there is no express reference to any of these; however, the element "illicit act" in the forfeiture action is exactly compatible with that of "corpus delicti."

Keywords: Forfeiture; Civic action elements; Crime theory; Causalism; Corpus delicti; Illicit act.

SUMARIO: 1. Introducción. 2. Concepto. Fundamento constitucional y legal de la acción de extinción de dominio (AED). 3. Elementos legales de la AED. 3.1. Primer elemento legal: la realización de un hecho ilícito como punto de conexión. 3.1.1. Concepto y evolución de la Teoría del delito. 3.1.1.1. El sistema Causalista. 3.1.1.2. El sistema Finalista. 3.1.1.3. El sistema Funcionalista. 4. La orientación sistemática-penal en México. 4.1. Primera Época. Causalismo (1857-1993). 4.2. Segunda Época. Finalismo (1993-1999). 4.3. Tercera Época. Causalismo "afinalizado" (1999-2008). 4.4. Cuarta Época. Sistema acusatorio (2008-fecha actual). 4.5. Nota marginal. El Funcionalismo en la legislación tabasqueña de adolescentes. 5. Balance. 6. Conclusiones. 7. Referencias.

2 Se utiliza el vocablo "forfeiture", de "criminal forfeiture", que significa "confiscación”, por ser el más cercano semánticamente al idioma español; empero, debe destacarse que la extinción de dominio en México no es una confiscación, la cual se encuentra prohibida por la Constitución en su artículo 22. La confiscación se orienta hacia la afectación de la economía del crimen y abarca la totalidad del patrimonio del inculpado, no bienes específicos. Véase: COTA MURILLO, Saúl. Definición de extinción de dominio y diferencias con otras instituciones que afectan la propiedad (confiscación, decomiso, adjudicación de bienes abandonados y expropiación). En: MARROQUÍN ZALETA, Jaime Manuel (Coordinador), Extinción de dominio, México: Instituto de la Judicatura Federal-Porrúa, 2009, p. 5. 


\section{INTRODUCCIÓN}

En el contexto de la globalización y la lucha contra el crimen organizado, se han adoptado legislaciones novedosas que otorgan nuevas facultades a la autoridad ejecutiva o que establecen mecanismos que facilitan la resolución ${ }^{3}$; fenómeno que ha cundido en el mundo entero, como una reconducción de la intervención punitiva del Estado, es decir, una auténtica expansión que replantea las garantías clásicas tanto del Derecho penal sustantivo, como del Derecho procesal penal y que desde luego, repercuten de modo general en el sistema jurídico.

Tal es el caso de la acción de extinción de dominio (AED), contemplada en el artículo 22 de la Constitución Política de los Estados Unidos Mexicanos (CPEUM) y desarrollada en la Ley Nacional de Extinción de Dominio (LNED). Acción híbrida, pues presenta connotaciones penales (el punto de conexión es un delito), civiles (es una acción real, en jurisdicción civil) y de derecho administrativo (en cuanto al destino de los bienes), enfrentando al Estado -representado en el Ministerio Público, como actor procesal- contra a un "enemigo presunto" (la parte demandada): el titular o poseedor de un bien producto o utilizado para o en la comisión de ciertos hechos ilícitos, quien verá disminuidos sus derechos, en comparación con otra especie de litigios del orden civil -de donde abreva su identidad, acorde a la CPEUM-.

En el presente trabajo se aborda uno de los elementos de dicha acción ${ }^{4}$ (la existencia o realización de un hecho ilícito); es decir, el "punto de conexión", que dado el carácter independiente de la AED, habrá de analizar el juez especializado en extinción de dominio y el cual implica el retorno de una teoría (penal) como la Causalista y el concepto del cuerpo del delito, que -al menos normativamente- ya había sido abandonada en México.

3 LABARDINI, Rodrigo. Los derechos humanos en la lucha contra el terrorismo. En: ARJONA, Juan Carlos; HARDAGA, Cristina (Coordinadores.). Terrorismo y derechos humanos, México, Fontamara, 2008, p. 486

4 Los elementos de la AED se enuncian en el artículo 9 de la LNED y son: a) la existencia o realización de un hecho ilícito; b) la existencia de algún bien de origen o destinación ilícita; c) el nexo causal de los dos elementos anteriores, y d) el conocimiento que tenga o deba haber tenido el titular, del destino del bien al hecho ilícito, o de que sea producto del ilícito. 
En efecto, el foco de atención de este ensayo, se sitúa solamente en el primero de los elementos de la AED, sin soslayar la importancia capital de los restantes. Ello por dos razones fundamentales. La primera de ellas es que, inicialmente los jueces de extinción de dominio, serán jueces civiles (como es el caso del Estado de Yucatán) ${ }^{5}$ que no se encuentran, por decirlo de una manera "empapados" de tópicos penales, necesarios en su comprensión para dar por acreditado ese elemento de la acción. En segundo lugar, porque el término de "hecho ilícito" pudiese utilizarse superficialmente y darle una connotación de sinónimo de "delito", en tanto que éste en sí, sería un concepto mucho más amplio.

Así las cosas, el planteamiento del problema se puede resumir en lo que a continuación se pregunta: ¿Cuál es significado del concepto de "hecho ilícito" en el contexto de la AED? ¿Es el concepto de "cuerpo del delito" una referencia válida al de "hecho ilícito"? ¿La dosis de prueba o el estándar probatorio en relación con el "hecho ilícito", es el mismo referente al del "cuerpo del delito" o al del "delito" per se?

5 La LED presenta una compleja serie de facultades concurrentes competenciales entre Estados y Federación. En efecto, el artículo 17 de la LNED dispone de una competencia concurrente en la materia, entre la Federación y los Estados, pues refiere que será autoridad competente por materia para conocer, substanciar y resolver en primera instancia los procesos de extinción de dominio, la persona titular del juzgado competente en materia de extinción de dominio, ya sea de la Federación o de las Entidades Federativas; bajo las siguientes reglas: 1) Será Juez competente, aquel que corresponda al del lugar donde sucedieron los hechos ilícitos o el que corresponda a la ubicación de los bienes. 2) A falta de ubicación de los bienes será Juez competente el del lugar del domicilio de la parte demandada, a elección del Ministerio Público. 3) Los citados juzgados conocerán de las acciones de extinción de dominio que ejerza el Ministerio Público, sin perjuicio del valor de los bienes objeto de la acción. 4) Será Juez competente el que prevenga en el conocimiento del asunto, sin perjuicio del fuero. 5) Cuando varios jueces conozcan del mismo asunto, continuará substanciando el proceso el Juez respectivo por prevención. 6) El Poder Judicial de la Federación y aquéllos de las Entidades Federativas contarán con juzgados competentes en materia de extinción de dominio, determinando por conducto de sus órganos facultados para ello, el número de juzgados necesarios de acuerdo a las cargas de trabajo, distribuidos en circuitos, distritos o cualquier otra forma de competencia territorial, de conformidad con las leyes orgánicas, reglamentos, acuerdos y demás normatividad aplicable. 
Para contestar lo anterior, es menester identificar qué es lo que se entiende por delito; por ende, se requiere echar mano de la Teoría del delito y las denominadas sistemáticas penales, que regularmente se reconocen como: Causalismo, Finalismo y Funcionalismo. En esa labor, se verificará un estudio descriptivo y comparativo, a fin de llegar a las correspondientes conclusiones.

Es la primera sistemática, el Causalismo la que presenta el concepto del cuerpo del delito, cuyo contenido se debatió durante mucho tiempo en México. Asimismo, la abrogada Ley Federal de Extinción de Dominio (LFED) aludió expresamente en su artículo 2, fracción II, a que por hecho ilícito debía entenderse la noción del cuerpo del delito, en términos del artículo 168 del Código Federal de Procedimientos Penales -igualmente abrogado a la fecha y sustituido por el Código Nacional de Procedimientos Penales (CNPP)-.

La actual LNED ya no refiere al cuerpo del delito ni la CPEUM, empero sí lo hace la jurisprudencia de la Suprema Corte de Justicia de la Nación (SCJN) -máximo órgano judicial en el país acorde al artículo 94 de la indicada Carta Magna.

La hipótesis que se formula es la siguiente: "Si el hecho ilícito como elemento de la AED en México implica la demostración del suceso criminal con abstracción de los diversos elementos del delito, como la culpabilidad, la antijuridicidad o la imputabilidad, entonces ello deriva de en que se acreditarán los elementos objetivos que constituyen la materialidad del hecho, por tanto, se percibe un regreso al concepto del cuerpo del delito, ya superado en el sistema penal, ahora presente en la jurisdicción civil".

\section{Concepto. Fundamento constitucional y legal de la acción de EXTINCIÓN DE DOMINIO (AED).}

El vocablo “extinción”, presenta dos significados: el primero (genérico), consistente en el hecho de extinguir o extinguirse un fuego o una luz ${ }^{6}$. El segundo, alude a la terminación o fin de una cosa, especialmente después de haber ido disminuyendo o desapareciendo poco a poco.

6 Real Academia Española. https://dle.rae.es/extinguir. 
A su vez, "dominio", implica la acción de dominar; supremacía (en cuanto al poder, la autoridad, la fuerza, etc.) que se tiene sobre algo $o$ alguien. En materia jurídica, la acepción expresa el poder que uno tiene de usar y disponer con libertad de lo que es suyo ${ }^{8}$. Se asimila al derecho de propiedad, entendido éste como el dominio que se ejerce sobre la cosa poseída? .

Por ende, la extinción de dominio será la terminación de la supremacía o poder de propiedad que se ejerce sobre una cosa.

En ese contexto, las constituciones suelen reconocer en su articulado, derechos de propiedad ${ }^{10}$ que significan toda una teoría social de un país y de sus habitantes sobre la economía de la producción y el destino o distribución de los bienes naturales y de los obtenidos por esa actividad productiva. De esta manera, se afirma que el derecho de propiedad es connatural y esencial a la persona ${ }^{11}$.

7 Deriva del latín dominus: señor, dueño propietario de una cosa (...) titular jurídico de un poder principal. GUTIĖRREZ-ALVIZ Y ARMARIO, Faustino. Diccionario de derecho romano. Madrid: Reus, 1982, p. 204.

8 PAlomar DE Miguel, Juan. Diccionario para juristas. México: Porrúa, Tomo I (A-I), 2008, p. 547.

9 MÁRQUEZ GONZÁlEZ, José Antonio. Propiedad. En: ÁlVAREZ DE LARA, Rosa María; BRENA SESMA, Ingrid; GONZÁLEZ ALCÁNTARA, Juan Luis (coords.). Diccionario de derecho civil y de familia. México: Porrúa, 2004, p.315.

10 En efecto, (...) la propiedad como objeto de regulación de los textos constitucionales aparece desde las primeras etapas del Estado constitucional, basta recordar que el artículo 16 de la Declaración de los derechos del hombre y del ciudadano de 1793 establecía que "El derecho de propiedad es el que tiene todo ciudadano para gozar, disponer, de acuerdo con su criterio, de sus bienes, de sus ganancias, del fruto de su trabajo, y de su laboriosidad". Antes incluso, la Declaración de 1789 dedicaba dos artículos a la propiedad- En su artículo $2^{\circ}$ se incluía a la propiedad entre "los derechos naturales e imprescriptibles del hombre", junto a la libertad, la seguridad y la resistencia a la opresión; por su parte, el artículo 17 de la misma Declaración de 1789 establecía el que seguramente es uno de primeros antecedentes de la expropiación, al menos consagrado a nivel supralegal; según este precepto: "Siendo la propiedad un derecho inviolable y sagrado, nadie puede ser privado de ella, salvo cuando lo exija evidentemente la necesidad pública, legalmente comprobada, y a condición de una indemnización justa y previa" (...). CARBONELL, Miguel. Los derechos fundamentales en México. México: Porrúa, 2005, p. 750.

11 CASTRO Juventino V. Garantías y Amparo. México: Porrúa, 2000, p. 232. 
En México, el derecho de propiedad se reconoce nominalmente en los primeros tres párrafos del artículo 27 de la CPEUM ${ }^{12}$. A su vez, ese derecho se encuentra protegido -junto con el de la posesión-, por el segundo párrafo del diverso artículo 14 de la propia CPEUM $^{13}$, desde el punto de vista de su afectación, cuando ésta se lleva a cabo sin el respeto de un debido proceso legal ${ }^{14}$.

Como se ha dicho, no solo la propiedad encuentra per se un ámbito de tutela constitucional, sino también la posesión.

Y ello no puede ser de otra manera, puesto que, en la actualidad, el mundo experimenta una economía de la impermanencia ${ }^{15}$; se observa una práctica reiterada en preferir las cosas en arrendamiento en vez de obtener su propiedad. Bienes inmuebles, artículos de uso en las casas,

12 (...) Artículo 27. La propiedad de las tierras y aguas comprendidas dentro de los límites del territorio nacional, corresponde originariamente a la Nación, la cual ha tenido y tiene el derecho de transmitir el dominio de ellas a los particulares, constituyendo la propiedad privada. Las expropiaciones sólo podrán hacerse por causa de utilidad pública y mediante indemnización. La nación tendrá en todo tiempo el derecho de imponer a la propiedad privada las modalidades que dicte el interés público, así como el de regular, en beneficio social, el aprovechamiento de los elementos naturales susceptibles de apropiación, con objeto de hacer una distribución equitativa de la riqueza pública, cuidar de su conservación, lograr el desarrollo equilibrado del país y el mejoramiento de las condiciones de vida de la población rural y urbana. En consecuencia, se dictarán las medidas necesarias para ordenar los asentamientos humanos y establecer adecuadas provisiones, usos, reservas y destinos de tierras, aguas y bosques, a efecto de ejecutar obras públicas y de planear y regular la fundación, conservación, mejoramiento y crecimiento de los centros de población; para preservar y restaurar el equilibrio ecológico; para el fraccionamiento de los latifundios; para disponer, en los términos de la ley reglamentaria, la organización y explotación colectiva de los ejidos y comunidades; para el desarrollo de la pequeña propiedad rural; para el fomento de la agricultura, de la ganadería, de la silvicultura y de las demás actividades económicas en el medio rural, y para evitar la destrucción de los elementos naturales y los daños que la propiedad pueda sufrir en perjuicio de la sociedad (...).

13 (...) Artículo 14. (...) Nadie podrá ser privado de la libertad o de sus propiedades, posesiones o derechos, sino mediante juicio seguido ante los tribunales previamente establecidos, en el que se cumplan las formalidades esenciales del procedimiento y conforme a las Leyes expedidas con anterioridad al hecho. (...).

14 PENICHE LÓPEZ, Vicente. Garantías y Amparo. México: Suprema Corte de Justicia de la Nación- Benemérita Universidad Autónoma de Puebla, 2007, p. 178.

TOFFLER, citado por CASTRO, Juventino V., en op. cit., p.237. 
transportes, ropas, maquinarias y demás bienes tanto de uso personal como aplicadas en actividades económicas, cada vez más se prefiere alquilarlas que adquirirlas en propiedad, como forma de garantizar el uso de dichos bienes, pero a la par gozar de sus mejoras y desarrollos, dado que se perfeccionan rápidamente y se produce su obsolescencia en escaso margen de tiempo, en virtud del avance tecnológico vertiginoso que corresponde a nuestra época.

Regresando al tema de la propiedad privada, ésta se encuentra garantizada en la CPEUM como un derecho, si bien sujeto a limitaciones ${ }^{16}$.

Una limitación se descuella del párrafo tercero del artículo 27 de la CPEUM, que es el fundamento de una facultad conferida a la autoridad para considerar a la propiedad bajo su aspecto de función social. Se expresa que la Nación tiene en todo tiempo el derecho de imponer a la propiedad privada (y por añadidura a la posesión) las modalidades que dicte el interés público, así como regular en beneficio social el aprovechamiento de los elementos naturales susceptibles de apropiación.

Otra limitante es la expropiación por causa de utilidad pública y mediante el pago de una indemnización (párrafo segundo del artículo 27 de la CPEUM) ${ }^{17}$.

16 En el entramado jurídico mexicano se encuentran varias limitaciones o modalidades impuestas a la propiedad; por ejemplo, la acción civil de prescripción positiva o usucapión hace perder al dueño la propiedad sobre un bien en favor del poseedor de éste por el transcurso del tiempo. Asimismo, utilizando un argumento "por minoría de razón”, si a la propiedad se le imponen límites constitucionales y legales, la posesión también puede ser afectada con aquéllos. Ejemplo de esto último son las medidas de protección contenidas tanto en las leyes de acceso de las mujeres a una vida libre de violencia, como en diversos códigos procesales de la república mexicana, que en atención al derecho fundamental a vivir en un entorno libre de violencia, disponen -entre otras- la extracción de la pareja violenta del domicilio en cohabitación y el reingreso al mismo de la pareja víctima, ello con independencia de los derechos de propiedad y posesión del presunto agresor. Véase: Tesis 1a.CIX/2016 (10a.), Gaceta del Semanario Judicial de la Federación, Décima Época, libro 29, abril de 2016, t. II, p. 1152, núm. de registro: 2011440, rubro: "Violencia familiar. Las medidas de protección en la materia, previstas en el artículo 2,355 del código de procedimientos civiles del Estado de México, son constitucionales".

17 El dominio del Estado se integra, en primer término, por aquellos bienes adquiridos originalmente por el Soberano por medio de la conquista, no 
Una tercera limitación es la extinción de dominio.

El 9 de agosto de 2019, se publicó en el Diario Oficial de la Federación (DOF $)^{18}$, el decreto por el cual se expidió la Ley Nacional de Extinción de Dominio (LNED) ${ }^{19}$, que completa las reformas a los artículos 22 y 73, fracción XXX, ambos de la CPEUM -DOF de 14 de marzo de 2019-.

La actual redacción del artículo 22 de la CPEUM, es del siguiente tenor:

(...) Artículo 22. Quedan prohibidas las penas de muerte, de mutilación, de infamia, la marca, los azotes, los palos, el tormento de cualquier especie, la multa excesiva, la confiscación de bienes y cualesquiera otras penas inusitadas y trascendentales. Toda pena deberá ser proporcional al delito que sancione y al bien jurídico afectado.

No se considerará confiscación la aplicación de bienes de una persona cuando sea decretada para el pago de multas o impuestos, ni cuando la decrete la autoridad judicial para el pago de responsabilidad civil derivada de la comisión de un delito. Tampoco se considerará confiscación

llegaron a salir de su patrimonio en virtud de haber sido declarados inalienables. En segundo lugar, por aquellos bienes que el Estado va adquiriendo como consecuencia de sus transacciones con los particulares, y en tercer lugar, por los que el propio Estado adquiere por virtud de aplicación de determinadas leyes. Como las de nacionalización y de bienes vacantes. Pero puede suceder que el Estado necesite para algunas de sus atenciones, bienes que formen parte de la propiedad privada y no pueda obtenerlos mediante arreglos contractuales con sus dueños. Como en tal caso el cumplimiento de las atribuciones del Estado sufriría sensiblemente si los medios necesarios sólo fueran administrados cuando concurre la voluntad de un particular, desde tiempos remotos se ha reconocido en la legislación una forma por la que el Estado puede unilateralmente llegar a adquirir esos bienes. Esa institución es la expropiación por causa de utilidad pública, definida como (...) un medio por el cual el Estado impone a un particular la cesión de su propiedad por una causa de utilidad pública y mediante la compensación que al particular se le otorga por la privación de esa propiedad (...). FRAGA, Gabino. Derecho Administrativo. México: Porrúa, 1991, pp. 374-375.

18 Medio de comunicación oficial en México, por el cual se da publicidad a leyes y decretos.

19 Decreto virtud al cual, a la par se reforman y adicionan diversas disposiciones del Código Nacional de Procedimientos Penales, de la Ley Federal para la Administración y Enajenación de Bienes del Sector Público, de la Ley de Concursos Mercantiles y de la Ley Orgánica de la Administración Pública Federal. 
el decomiso que ordene la autoridad judicial de los bienes en caso de enriquecimiento ilícito en los términos del artículo 109, la aplicación a favor del Estado de bienes asegurados que causen abandono en los términos de las disposiciones aplicables, ni de aquellos bienes cuyo dominio se declare extinto en sentencia.

La acción de extinción de dominio se ejercitará por el Ministerio Público a través de un procedimiento jurisdiccional de naturaleza civil y autónomo del penal. Las autoridades competentes de los distintos órdenes de gobierno le prestarán auxilio en el cumplimiento de esta función. La ley establecerá los mecanismos para que las autoridades administren los bienes sujetos al proceso de extinción de dominio, incluidos sus productos, rendimientos, frutos y accesorios, para que la autoridad lleve a cabo su disposición, uso, usufructo, enajenación y monetización, atendiendo al interés público, y defina con criterios de oportunidad el destino y, en su caso, la destrucción de los mismos.

Será procedente sobre bienes de carácter patrimonial cuya legítima procedencia no pueda acreditarse y se encuentren relacionados con las investigaciones derivadas de hechos de corrupción, encubrimiento, delitos cometidos por servidores públicos, delincuencia organizada, robo de vehículos, recursos de procedencia ilícita, delitos contra la salud, secuestro, extorsión, trata de personas y delitos en materia de hidrocarburos, petrolíferos y petroquímicos.

A toda persona que se considere afectada, se le deberá garantizar el acceso a los medios de defensa adecuados para demostrar la procedencia legítima del bien sujeto al procedimiento (...).

Prima facie, debe decirse que la extinción de dominio apareció en el sistema jurídico mexicano desde hace 11 años, vía una inicial reforma al artículo 22 (DOF de 18-junio-2008).

Desde el punto de vista constitucional, dicha acción no es una confiscación ni, por ende, pena inusitada o trascendental (prohibidas por la Ley Fundamental), pues si bien su objeto es privar del derecho de propiedad a una persona, tal institución implica un régimen de excepción para combatir sobre todo a la delincuencia organizada y a otra especie de delitos, de manera que la privación que deriva de ese procedimiento jurisdiccional se da exclusivamente respecto a bienes que son instrumento, objeto o producto de alguno de esos hechos típicos (enumerados en la 
misma norma), mediante el seguimiento de un procedimiento en el que debe respetarse la garantía de audiencia.

En efecto, la incorporación de la extinción de dominio a nuestro sistema jurídico remonta hacia el año 2008, y formó parte de un paquete de reformas dirigidas a dar un trato especial a cierto tipo de delincuencia.

Dicha motivación generó varias modificaciones al texto constitucional (entre ellas, las adiciones a los artículos 16, 18, 19 y 20), dada la necesidad de contar con herramientas especiales para combatir la delincuencia organizada, que se distingue por sus características especiales en su capacidad de operación, la sofisticación de sus actividades, el impacto social de los delitos que comete y su condición de amenaza en contra del Estado.

Como lo reconoció el poder reformador de la constitución, tal organización ha rebasado la capacidad de respuesta de las autoridades.

Por estas razones, se identificaron los delitos específicos con las siguientes finalidades: a) Afectar a la delincuencia organizada en su patrimonio; b) Debilitar su estructura; c) Aumentar sus costos; d) Reducir sus ganancias; e) Dificultar su operación; y f) Combatirla de manera frontal ${ }^{20}$.

La actual redacción del artículo 22 de la CPEUM, abarca una amplitud importante en relación con los ilícitos objeto de la acción de mérito, pues no solamente comprende a la delincuencia organizada, sino también a "hechos de corrupción" y "delitos cometidos por servidores públicos”, los cuales no necesariamente se verifican a través de aquella figura de pluridelincuencia.

Desde su lectura constitucional, la extinción de dominio no tiene por objeto sancionar al responsable de la comisión del hecho ilícito; antes bien, está dirigida al apoderamiento de los bienes que son instrumento y producto del delito.

Difiere de la expropiación en que la extinción de dominio no obedece a una causa de utilidad pública, sino a la existencia de un hecho ilícito con resultados patrimoniales provechosos obtenidos al margen

20 MELÉNDEZ ALMARÁZ, Mireya. Artículo 22. En: Cossío Díaz, José Ramón (coord.). Constitución Política de los Estados Unidos Mexicanos Comentada. México: Tirant lo Blanch, 2017, p. 514. 
de la ley o, en caso de que un bien hubiese sido la vía o el medio para la realización del injusto.

Otra diferencia con la expropiación, reside en que en la extinción de dominio el Estado no paga una indemnización al propietario.

Un tercer criterio diferenciador consiste en que la expropiación es reversible, en tanto que la extinción de dominio no.

Debe decirse que desde 2008 convivieron en el ordenamiento jurídico tanto la Ley Federal de Extinción de Dominio, como leyes estatales en la materia, con las consabidas incongruencias; por tanto el Congreso de la Unión se irrogó la facultad para expedir la legislación única en la materia, la cual vio la luz -como se ha indicado-, el 9 de agosto de $2019^{21}$.

\section{Elementos legales de la AED.}

Por elementos "legales" de la acción, entendemos las condiciones específicas que la normatividad contempla para ejercitarla.

En ese contexto, la AED es, en primer orden autónoma, por disposición del párrafo tercero del artículo 22 de la CPEUM. Respecto de esta característica, el diverso párrafo tercero del numeral 8 de la LNED, especifica que el proceso (leamos "acción") de extinción de dominio será autónomo, distinto e independiente de aquel o aquellos de materia penal de los cuales se haya obtenido la información relativa a los hechos que sustentan la acción o de cualquier otro que se haya iniciado con anterioridad simultáneamente.

La calificativa de autonomía de la acción, consiste en la facultad conferida al juzgador, acorde al segundo párrafo del artículo 14 de la LNED para resolver sobre los elementos de la acción con "plenitud de jurisdicción”.

Estos elementos se enuncian en el artículo 9 de la LNED y son: a) la realización de un hecho ilícito; b) la existencia de algún bien de origen o destinación ilícita; c) el nexo causal de los dos elementos anteriores, y

21 Todos los estados de la federación y el Distrito Federal (ahora Ciudad de México), contaron con leyes locales de extinción de dominio, excepto Yucatán. 
d) el conocimiento que tenga o deba haber tenido el titular, del destino del bien al hecho ilícito, o de que sea producto del ilícito.

De tal manera que el juez de extinción de domino no queda vinculado totalmente con lo resuelto en la causa penal de la cual emerge el ejercicio de la acción, pues podrá calificar, por ejemplo, el punto de conexión entre ambos enjuiciamientos -el hecho ilícito (delito)- de distinta forma de la que se hizo en la jurisdicción criminal.

Si bien se afirmó en líneas precedentes que la acción de extinción de dominio tiene su causa petendi en la existencia de un hecho ilícito derivado de las pruebas que existen en una averiguación previa o en un procedimiento penal, el simple hecho de que aquella se funde en esta especie de evidencia, no desdice ni contradice la autonomía que de esa acción establece el artículo 22 de la CPEUM.

En efecto, el origen del hecho ilícito y su existencia, se surten a partir de las actuaciones penales, por lo que es ese hecho el que constituye el fundamento fáctico de dicha acción; mientras que la autonomía se actualiza con relación a la sentencia que se dicte.

Es decir, que no dependerá de que se determine la responsabilidad del procesado, porque ni siquiera su muerte incide en el curso de la acción de extinción de dominio. Tan es así, que el Juez de extinción de dominio puede tramitar la acción y resolverla aunque no exista auto de vinculación a proceso o un pronunciamiento en sentencia sobre la responsabilidad del acusado en la comisión del hecho ilícito, incluso, aunque no exista una persona determinada a la cual inculpar, porque lo relevante es que:

a) Exista certeza de que hubo un hecho ilícito que encuadra en uno de los delitos que da lugar a la acción de extinción de dominio.

b) Se sustente en la información que recabe el Ministerio Público cuando se haya iniciado la averiguación previa o una investigación o que se sustente en las actuaciones conducentes del procedimiento penal respectivo.

Entonces, la dosis de prueba redundará en el enjuiciamiento de extinción de dominio, en primer orden, cuando de esas actuaciones se desprenda que el hecho ilícito sucedió y que los bienes se ubican en los supuestos normativos. 
Por tanto, la acción de extinción de dominio no depende de los actos que realiza el Juez penal, sino de las actuaciones, datos o medios de prueba que en la instancia criminal se desahoguen.

De esa manera, se consagra la autonomía del juzgador de la acción de extinción de dominio en la toma de decisiones, puesto que garantiza su absoluta libertad para resolver sobre la procedencia o improcedencia de la acción.

Al respecto, la jurisprudencia ha identificado dos posibles escenarios:

1. Cuando en la causa penal se determine la falta de alguno de los elementos del hecho ilícito. Tal disociación no se aplica en la calificación de los elementos del injusto, pues en cuanto a ese preciso aspecto, existe una vinculación total, de manera que, generalmente, el Juez de Extinción de Dominio debe sujetarse a la decisión que adopte el especializado en la materia penal cuando éste concluye, en una resolución intraprocesal que los elementos del cuerpo del delito no quedaron acreditados, o al dictar la sentencia definitiva, que el delito no se demostró ${ }^{22}$.

2. Cuando la acción inicia con base en una resolución del Juez penal en la que determinó la existencia del hecho ilícito. En este caso debe tenerse como un elemento de prueba para demostrar su existencia, pero corresponde a las partes aportar los elementos necesarios a juicio para acreditar los extremos de sus pretensiones, ya que la litis es determinar si procede o no la extinción del derecho real de propiedad de los bienes y no respecto de la responsabilidad del acusado en la comisión del hecho ilícito ${ }^{23}$.

22 Tesis 1a./J. 21/2015 (10a.), Gaceta del Semanario Judicial de la Federación, Décima Época, libro 17, abril de 2015, t. I, p. 340, núm. de registro: 2008879, rubro: "Extinción de dominio. La autonomía a que se refiere el artículo 22 de la Constitución Política de los Estados Unidos Mexicanos, entre el procedimiento relativo y el penal no es absoluta, sino relativa.".

23 Tesis I.15o.C.31 C (10a.), Gaceta del Semanario Judicial de la Federación, Décima Época, libro 67, junio de 2019, t. VI, p. 5076, núm. de registro: 2020154, rubro: "Acción de extinción de dominio. La autonomía de ésta consiste en la 
Los cuatro elementos de la acción de extinción de dominio enumerados en el artículo 9 de la LNED, pueden denominarse de la siguiente forma:

a) El elemento o punto de conexión (el hecho ilícito);

b) El elemento real (la existencia de bienes de origen o destinación ilícita);

c) El elemento lógico (nexo de causalidad entre "a" y "b"); y

d) El elemento cognoscitivo (que el sujeto pasivo de la acción actúe a sabiendas de la ilicitud).

Para efectos de este trabajo, nos enfocaremos en el primero de ellos.

\subsection{Primer elemento legal: la realización de un heCho ilícito como punto DE CONEXIÓN}

La referencia al "hecho ilícito" está asignada a un evento que encuadra en alguno de los tipos penales que establece el artículo 22 de la CPEUM (típico), y que es contrario a derecho (antijurídico). Le llamamos el punto de conexión, pues es el puente entre dos jurisdicciones: la penal y la de extinción de dominio (civil).

Aquí es donde los civilistas se verán en la necesidad de empaparse de tópicos de derecho penal.

Según la $\mathrm{SCJN}^{24}$, ese punto de conexión guarda relación directa con el concepto de "cuerpo del delito", utilizado en el sistema procesal penal tradicional mixto, y que ahora es denominado hecho ilícito ${ }^{25}$,

libertad del juzgador para resolver sobre su procedencia o improcedencia, con independencia de que tenga su origen en un hecho ilícito, derivado de pruebas que consten en la averiguación previa o procedimiento penal.".

24 Tesis 1a./J. 20/2015 (10a.), Gaceta del Semanario Judicial de la Federación, Décima Época, libro 17, abril de 2015, t. I, p. 330, núm. de registro: 200887, rubro: "Extinción de domino. Concepto de hecho ilícito para efectos de la acción relativa (legislación del distrito federal).”.

25 La CPEUM ha incluido expresamente, en los artículos 14 y 16 cuestiones atinentes a la teoría del delito, como baremos de imputación procesal penal, perfilándose en un momento dado hacia la "Teoría final de la acción" (elementos del tipo) o hacia la "Teoría causalista" (cuerpo del delito). Asimismo, 
para referirse a la acción u omisión considerada como delito por la ley penal, en el entendido de que su constatación es a título descriptivo y despersonalizado; es decir, excluye la culpabildad.

Entonces, para comprender lo anterior, resulta menester acudir a los elementos que nos brinda la teoría del delito, como una referencia obligada.

\subsubsection{CONCEPTO Y EVOLUCIÓN DE LA TEORÍA DEL DELITO ${ }^{26}$}

El análisis de las ciencias penales nos permite entrever la serie de materias que conforman su contenido, algunas con un carácter eminentemente dogmático y otras puramente técnicas, pero al referir su ámbito es preciso ubicar a la parte de la ciencia encargada de efectuar la tarea del análisis y sistematización de los elementos que la abarcan, siendo la teoría la encargada de aportar las explicaciones respectivas ${ }^{27}$.

La teoría del delito se ocupa de los presupuestos jurídicos de la punibilidad de una acción. Se incluyen ahí no solo los delitos propiamente dichos, sino todas las acciones punibles. Si se habla de los presupuestos de la punibilidad, se piensa primero, de manera natural, en la Parte Especial del Derecho Penal, donde se hallan regulados los distintos tipos penales, como homicidio, robo, daño en propiedad ajena, fraude, etc. Sin embargo, la teoría del delito no estudia los elementos de cada uno de los tipos de delito, sino aquellos componentes del concepto de delito que son comunes a todos los hechos punibles. Se trata, particularmente, de las categorías de la tipicidad, antijuridicidad y culpabilidad, que se dividen a su vez en

la gran reforma en materia de seguridad y justicia penal de 2008, prescindió de tales referencias a una teoría en específico. Por su parte, las técnicas de litigación oral sugieren el planteamiento de la denominada "Teoría del caso", consistente en la exposición que cada una de las partes verifica frente al juzgador, respecto de su correspondiente versión de los hechos y con base en los datos que cada una de ellas aporte al proceso.

Véase un trabajo previo: RIVERO EVIA, Jorge. "A propósito de la teoría del delito: ¿Es aún necesaria en el sistema acusatorio mexicano?”. Revista In Iure Anáhuac Mayab, 2017, año 5, 10, ISNN 2007-6045, pp. 75-107.

27 PLASCENCIA VILLANUEVA, Raúl. Teoría del delito. Serie G: Estudios doctrinales, núm. 192. México: UNAM- Instituto de Investigaciones Jurídicas, 1998, p. 11. 
numerosos subconceptos, como elementos objetivos y subjetivos del tipo, presupuestos objetivos y subjetivos de las causas de justificación, y elementos positivos y negativos de la culpabilidad.

Interesa entonces la cuestión acerca de en qué condiciones un hecho puede ser imputado al autor a nivel del correspondiente delito ${ }^{28}$.

Para los fines del presente trabajo, se toman en cuenta tres sistemas: el Causalista, el Finalista y el Funcionalista, con la aclaración de que la intención no es desarrollar de manera profunda las ideas que dieron pie a esas corrientes doctrinales, pues esa tarea se la reservamos a tratados específicos de la Teoría del Delito y en el caso que nos ocupa se pretende solamente establecer su relación con uno de los elementos de la acción de extinción de dominio.

\subsubsection{El sistema Causalista}

El sistema jurídico penal llamado "Causalista", nació a partir de la obra de Franz Von Liszt, quien se apoyó en el concepto de "acción”, como un fenómeno causal natural como punto de partida del delito ${ }^{29}$.

Liszt recogió las ideas de la escuela Clásica y la Positivista y aplicando el método naturalístico, en boga a finales del siglo XIX, emprendió el estudio del Código Penal Alemán de 1871, para desprender de dicho cuerpo legislativo la estructura del delito, naciendo así la dogmática jurídico penal, que no es otra cosa más que el conocimiento del delito, a través del dogma, que es la ley.

Para el código punitivo germánico de 1871, el delito es la acción sancionada por las leyes penales. De esta definición legal y de las demás disposiciones de esa ley, Von Liszt realizó un análisis sistemático del derecho penal y del delito, y partiendo de una base naturalística, causalista, que es el acto o la acción humana; por ende, su teoría fue denominada "Causalista", que comprende a toda la doctrina

28 JESCHECK, Hans-Heinrich. Tratado de Derecho Penal (Parte General), $4^{\mathrm{a}}$. Granada: Comares, 1993, p. 175.

29 Véase: VON LISZT Franz. Tratado de derecho penal. Buenos Aires: Valetta Ediciones, 2007. 
que acepta como punto de arranque de la teoría del delito, la explicación naturalística del acto o la acción. ${ }^{30}$

Para este sistema, la explicación del acto o acción humana, se fundamenta en relaciones de procesos causales. La acción nace de un movimiento corporal que es un proceso, que origina un cambio en el mundo exterior, es decir, un efecto, y entre una y otro se da una relación.

Sobre la denominación que debe de recibir la "acción" como elemento del delito, se han utilizado conceptos como acto, conducta, hecho, acontecimiento, etc. En lo atinente a la naturaleza del acto o acción, se plantea la discusión de la imposibilidad de unificar los conceptos de acción y de omisión en uno solo que los abarque. Otro punto de debate ha sido el que considera al acto o acción dependiente de la imputabilidad; otros lo refieren al injusto. A la par, surge la discusión a que el acto o acción es "acromático", frente a quienes otorgan a la acción un valor "cromático" o finalista. ${ }^{31}$

En general, puede decirse, siguiendo el pensamiento más avanzado del sistema causalista, que la "omisión" se presenta cuando no se realiza el movimiento corporal "esperado" que debía de producir un cambio en el mundo exterior, violándose una norma imperativa (en la acción la norma es prohibitiva).

Todavía resulta más controversial el concepto de la comisión por omisión donde se afirma que se produce un resultado material a través de una omisión, de ahí que en este supuesto se violen tanto una norma imperativa como una prohibitiva.

En la teoría causalista en el estudio del acto o acción, lo que interesa es la fase externa; la interna corresponde a otro nivel, es decir, a la culpabilidad donde se analiza si el contenido de la voluntad fue doloso o culposo. En esa virtud, surge la figura del “cuerpo del delito", entendido como el conjunto de elementos externos de la conducta que reflejan la

30 PLASCENCIA VILLANUEVA, Raúl, op. cit., pp. 10-11.

31 Es decir, con independencia del dolo o las calificativas del delito ("acromático", o sea, sin color); este criterio es la distinción clave que el Causalismo presenta frente al Finalismo, que se dice es "cromático", pues enfatiza en la "finalidad de esa acción” (dolosa o culposa). Véase: ORELLANA WIARCO, Octavio Alberto, Teoría del delito. Sistemas Causalista, Finalista y Funcionalista. Teoría del delito y Teoría del Caso. México, Porrúa, 2020. p. 12. 
existencia de un hecho. La acción es un factor de orden naturalístico desencadenante de un resultado material; es simple y sencillamente, un proceso causal. ${ }^{32}$

Es Vives Antón ${ }^{33}$ - según el punto de vista de quien escribe estas líneas- quien mejor explica el concepto naturalístico de acción, que permite vincularlo a la idea del cuerpo del delito:

\begin{abstract}
“(...) si el delito es básicamente acción a la que se sobreañaden tipicidad, antijuridicidad y culpabilidad, parece claro que la acción ha de ser el género común del que quepa desgajar las diversas especies delictivas (...) Juega así el concepto de acción un papel semejante al de cuerpo: los sólidos, líquidos o gases son estados de la materia o, dicho en lenguaje ordinario, clases de cuerpos que se delimitan porque, como tales, presentan ciertas características específicas que, en todo caso, remiten a una condición material común (...)”.
\end{abstract}

\title{
3.1.1.2. EL SISTEMA FINALISTA
}

Hans Welzel es el indiscutible jurista que da nacimiento a la llamada "teoría de la acción finalista" que plantea una sistematización de la dogmática jurídico penal que se aparta de la sistemática "causalista". ${ }^{34}$

A partir de la década de 1930, aparecen publicados los trabajos de Welzel, que acepta que si bien el delito parte de una acción, y que ésta es conducta humana voluntaria, la misma tiene una finalidad; no como explica la teoría causalista que prescinde del contenido de la voluntad, o sea el fin. De esta diversa concepción se van a generar múltiples consecuencias que conforman la teoría finalista de la acción.

El fundador del finalismo explica que detrás de cada prohibición o mandato se hallan los elementales deberes ético-sociales, cuya vigencia se asegura conminando con una pena la lesión de esos deberes, pero la pena

32 Ibidem, p. 11

33 VIVES ANTÓN, Tomás S. Fundamentos del sistema penal. Valencia: Tirant lo Blanch, 1996, p. 105.

34 QUINTINO ZEPEDA, Rubén. La ciencia penal a través de sus autores. México: Flores Editores, 2009, pp. 64-65. 
debe dirigirse solo a la protección de los básicos deberes ético-sociales, como la vida, la libertad, el honor, etc. (principio de exclusividad de los medios punitivos específicos), pues extender la punición a conductas que no revistan gravedad de lesión a elementales deberes, degenera en un Estado represivo. ${ }^{35}$

La teoría finalista de la acción, maneja los conceptos ya expuestos por la teoría causalista, es decir, acción, tipicidad, antijuridicidad, imputabilidad, culpabilidad y punibilidad, pero tales conceptos son empleados con un esquema distinto, constituyendo un sistema que busca la solución técnica y práctica a cuestiones que la teoría causalista no resolvía satisfactoriamente.

El punto de partida de la teoría finalista de la acción, es como su nombre lo indica, una concepción distinta de la acción de la que maneja la teoría causalista.

Esa nueva teoría, hizo del concepto de la acción (finalísticamente entendida), la base de la estructura del delito. Según ello, el actuar humano pertenece a una categoría del ser totalmente distinta a cualquier otro proceso causal. Es "ejercicio de la actividad final". Con la ayuda de su saber causal, el hombre puede, dentro de ciertos límites, dominar el acaecer y dirigir conforme a un plan su actuación para alcanzar una meta. La dirección final de la acción se realiza en la anticipación mental de la meta, en la elección de los medios instrumentales precisos y en la ejecución de la acción en el mundo real. ${ }^{36}$

Se asevera que la teoría causalista redujo el concepto de acción a un proceso causal; prescindiendo por completo de la vertiente de la finalidad. Con ello desconoció la realidad de las acciones humanas, que no son simples procesos causales (pues en este caso no se podrían diferenciar los fenómenos de la naturaleza), sino procesos causales dirigidos a un fin. O sea, al causalismo si bien le importa que el individuo haya actuado voluntariamente, no le es relevante lo que el sujeto haya querido (el contenido de su voluntad). ${ }^{37} \mathrm{Y}$ no es que el causalismo desconociera

35 Véase: WELZEL, Hans. Estudios de derecho penal. Buenos Aires: B de F, 2002.

36 JESCHECK, Hans-Heinrich, op. Cit., p. 191.

37 MUÑOZ CONDE, Francisco. Teoría general del delito, Valencia, Tirant lo Blanch, 1989, p. 26. 
esa afirmación del finalismo (que toda conducta se encuentra dirigida a fines), sino que en el concepto de acción, tales fines no debían ser considerados, por estimar que pertenecían a diverso elemento del delito (la culpabilidad).

Acorde con el principio de acción de la teoría causalista, tenemos que la acción es la manifestación de la voluntad por medio del movimiento corporal (o de la ausencia de este movimiento) que produce un resultado o cambio en el mundo exterior. Es pues, un proceso causal, donde la "acción" es la causa del resultado, ya que como proceso causal, naturalístico tiene que existir forzosamente un nexo causal entre la "acción" y su "resultado".

Ahora bien, para la teoría finalista de la acción, la acción humana es el ejercicio de una actividad finalista. La acción es, por lo tanto, un acontecimiento "finalista" y no solamente "causal". La "finalidad" o actividad finalista de la acción se basa en que el hombre, sobre la base de su conocimiento causal, puede prever en determinada escala las consecuencias posibles de una actividad, proponerse objetivos de diversa índole y dirigir su actividad según un plan tendiente a la obtención de sus objetivos. Por eso, se afirma la finalidad es "vidente" y que la causalidad es "ciega".

En efecto, el legislador cuando describe una conducta de tipo penal (por ejemplo: "quien prive a otro de la vida"), no describe un simple proceso causal (también un rayo puede causar la muerte de una persona), sino un proceso causal en la medida que se deriva de la realización de una acción final humana. ${ }^{38}$

Para la teoría finalista, la acción pasa por dos fases, una interna y una externa. En la interna, el autor se propone anticipadamente la realización de un fin. Por ejemplo: realizar un viaje. Para llevar a cabo este fin selecciona los medios necesarios (viajar en coche, tren, avión). Esta selección sólo puede hacerse a partir del fin. Es decir, sólo cuando el autor está seguro de qué es lo que quiere, puede plantearse el problema de cómo lo quiere. En esta fase interna tiene también que considerar los efectos concomitantes que van unidos a los medios elegidos y a la consecución del fin que se propone (si, por ejemplo, elige el coche como medio de viaje y éste es largo, sabe que tiene que parar para dormir, cuenta con

38 Ibidem, p. 27. 
una avería, etc.). La consideración de estos efectos concomitantes puede hacer que el autor vuelva a plantearse la realización del fin y rechace algunos de los medios seleccionados para su realización. Pero una vez que los admita, como de segura o probable producción, también esos efectos concomitantes pertenecen a la acción. ${ }^{39}$

En la fase externa, se presentan: a) la puesta en marcha, la ejecución de los medios para cristalizar el objetivo principal; b) el resultado previsto y el o los resultados concomitantes; y c) el nexo causal.

Es decir, una vez propuesto el fin, seleccionados los medios para su realización y ponderados los efectos concomitantes, el autor procede a su realización en el mundo externo; pone en marcha, conforme a un plan, el proceso causal, dominado por la finalidad, y procura alcanzar la meta propuesta.

Dicho en pocas palabras, en la teoría de la acción final, encontramos que el dolo y la culpa se van a ubicar, ya no en el ámbito de la culpabilidad, sino en el de la acción típica. Es decir, dejarán de ser especies o formas de la culpabilidad, como tradicionalmente lo aceptó la teoría causalista, para constituir ahora el fin de la acción.

\subsubsection{EL SISTEMA FUNCIONALISTA}

El derecho y sus instituciones, en particular el Derecho Penal y los organismos de procuración y administración de justicia, así como el aparato de seguridad pública, son funciones que responden a las exigencias de la estructura social.

Con frecuencia, podemos constatar que en nuestro campo de estudio (el Derecho Penal) se habla de crisis, de reformas, de nuevos modelos, es decir, del planteamiento de sistemas funcionales.

Generalmente los estudiosos de la materia punitiva no se proponen el cambio de la estructura social, se ocupan de la problemática de la función de las instituciones de procuración y administración de justicia, destacándose las reformas jurídico penales que permitan enfrentar con más eficacia al fenómeno de la criminalidad; así, se proponen cambios

39 ORELLANA WIARCO, Octavio Alberto, op. cit., p. 89 
en la legislación penal, pero sin una visión clara de la función que deben desempeñar, no existe percepción precisa del cometido que deban llevar a cabo; por ejemplo, se piensa en combatir la delincuencia simplemente con elevar las penas a las conductas típicas, suponiendo que ello bastará para desalentar los hechos delictivos, sin atender las raíces del problema. En México se piensa que basta cambiar la ley para cambiar la realidad, abundan los ejemplos y para muestra las múltiples reformas constitucionales que a su vez, recalan en una pléyade de adición normativa secundaria, en todas las ramas del derecho.

En el campo del derecho penal, en particular en la teoría del delito, ha surgido una sistemática denominada funcionalista, que es una de sus principales corrientes, misma que se ocupa de la función que la Política Criminal debe tener en el campo del derecho punitivo.

En palabras de Friedrich Nietzsche ${ }^{40}$ : "por regla general, el valor o el no valor de un precepto se demuestra por el hecho de que se consiga o no se consiga el resultado propuesto, siempre y cuando se siga aquél escrupulosamente".

Jescheck y Schüler-Springorum ${ }^{41}$ ven a la Política Criminal como una disciplina que se ocupa y preocupa de la criminalidad, del Derecho Penal, de las normas y de los valores.

Es decir, que el precepto o conjunto de preceptos (leyes) solo tienen valor si se consiguen las finalidades trazadas en un principio, y es mediante la Política Criminal como se podrá llegar a la consecución de la meta del derecho penal: la seguridad y la paz de las personas.

El funcionalismo se puede decir que surge en 1970 con las ideas del penalista germano Claus Roxin, ${ }^{42}$ quien consideró que la explicación de la llamada "teoría finalista de la acción", si bien superaba a la explicación del sistema causalista, tampoco era del todo satisfactoria, principalmente porque no resolvía la función que debía desempeñar la Política Criminal

40 NIETZSCHE, Friedrich. Aurora. Biblioteca conmemorativa Nietzsche. Aurora, El Anticristo, Madrid: Editorial Libsa, 2000, p. 26

41 BERISTÁIN IPIÑA, Antonio. Victimología. Nueve palabras clave. Valencia: Tirant Lo Blanch, 2000, pp. 554-555.

42 Véase: ROXIN, Claus. Derecho Penal. Parte General. Tomo I. Fundamentos, la estructura de la teoría del delito. Madrid: Civitas, 1999. 
en el campo del derecho penal, en especial en la teoría del delito. Su teoría se caracteriza por tres aspectos: ${ }^{43}$

a) La vinculación de la dogmática penal a ciertos fines político-criminales de carácter preventivo;

b) La responsabilidad penal entendida como la suma de la reprochabilidad, más el merecimiento y la necesidad de pena; y

c) La teoría de la imputación objetiva como un elemento regulador del nexo causal.

Así, la imputación objetiva de un resultado presupone positivamente dos puntos: la creación de un peligro jurídicamente desaprobado para el bien jurídico protegido y la realización de ese peligro en el hecho concreto causante del resultado.

Dicho de otro modo, para esta inclinación doctrinal, se requiere en primer lugar, que el autor haya creado un riesgo para el bien jurídico protegido (vida, libertad, propiedad, etc.), es decir, justamente con la violación de las normas penales que tienen por objeto la tutela ese valor.

\section{LA oRIENTACIÓN SISTEMÁtICA-PENAL EN MÉXICO}

Nuestro país ha adoptado en el devenir histórico, con mayor o menor énfasis, a cada una de estas teorías, como se verá a continuación.

\subsection{Primera Época. Causalismo (1857-1993).}

Nótese que, en primer lugar, la Constitución de 1857 no aludió a concepto sistemático alguno:

En efecto, la Constitución Federal de los Estados Unidos Mexicanos de 1857, contempló en los artículos 16 y 19 como título de imputación para detenciones, lo siguiente: ${ }^{44}$

43 QUINTINO ZEPEDA, Rubén, op. cit., p. 175.

44 CARBONELL, Miguel; CRUZ BARNEY, Óscar; PÉREZ PORTILLA, Karla (comps.). Constituciones históricas de México. México: Porrúa, 2004, p. 454. 
(...) Artículo 16.- Nadie puede ser molestado en su persona, familia domicilio, papeles y posesiones, sino en virtud de mandamiento escrito de la autoridad competente, que funde y motive la causa legal del procedimiento. En el caso de delito in fraganti, toda persona puede aprehender al delincuente y á sus cómplices, poniéndolos sin demora á disposición de la autoridad inmediata (sic) (...).

(...) Artículo 19.- Ninguna detención podrá esceder del término de tres días sin que se justifique con un auto motivado de prisión y los demás requisitos que establezca la ley (sic) (...).

A su vez, el Código de Procedimientos Penales de 1894 (promulgado por Porfirio Díaz), en su artículo 104, indicaba: “(...) Todos los delitos que por este código no tengan señalada una prueba especial, se justificarán comprobando todos los elementos que los constituyen, según la clasificación que de ellos haga el Código Penal, teniendo siempre presente lo dispuesto por éste en su artículo $9^{\circ}(. ..){ }^{*} .^{45}$

Por su parte, el artículo $9^{\circ}$, del Código Penal de 1871 (promulgado por Benito Juárez), establecía: (..) "Siempre que a un acusado se le pruebe que violó una ley penal, se presumirá que obró con dolo, a no ser que se averigüe lo contrario, o que la ley exija la intención dolosa para que haya delito". ${ }^{4}$

Compartimos la idea de Colín Sánchez ${ }^{47}$ cuando sostiene que los redactores del Código de Procedimientos Penales de 1894, identificaban al delito con el cuerpo del delito.

Ahora bien, la Constitución de 1917, en la redacción original (hoy pluri-reformada) de los propios artículos 16 y 19, refirió: ${ }^{48}$

(...) Artículo 16.- (...). No podrá librarse ninguna orden de aprehensión o detención, a no ser por la autoridad judicial, sin que proceda denuncia, acusación o querella de un hecho determinado que la ley castigue con pena corporal, y sin que estén apoyadas, por declaración,

45 DÍAZ DE LEÓN, Marco Antonio. Historia del derecho penal y procesal penal mexicanos. T. I. México: Porrúa, 2005, p. 627.

46 Ibidem, p. 361.

47 COLÍN SÁNCHEZ, Guillermo. Derecho mexicano de procedimientos penales. México: Porrúa, 1997, p. 376.

48 CARBONELL, Miguel; CRUZ BARNEY, Óscar; PÉREZ PORTILLA, Karla, op. cit., pp. 497-498. 
bajo protesta, de persona digna de fe o por otros datos que hagan probable la responsabilidad del inculpado, hecha excepción de los caso de flagrante delito, en que cualquiera persona puede aprehender al delincuente y a sus cómplices, poniéndolos sin demora ante la autoridad inmediata (sic). (...).

(...) Artículo 19.- Ninguna detención podrá exceder del término de tres días, sin que se justifique con un auto de formal prisión, en el que se expresarán: el delito que se impute al acusado; los elementos que constituyen aquél; lugar, tiempo y circunstancias de ejecución y los datos que arroje la averiguación previa, los que deben ser bastantes para comprobar el cuerpo del delito y hacer probable la responsabilidad del acusado (énfasis añadido). (...).

Como se observa, el concepto del cuerpo del delito se erigió como el título de imputación para justificar el auto de formal prisión en una Constitución mexicana desde 1917. Empero, el constituyente no definió qué era lo que se entendía por dicha entelequia.

Peniche López ${ }^{49}$ comenta que -en oposición a grandes juristas de esa época, como González Bustamante y Franco Sodi-, solamente en tratándose del auto de formal prisión y del dictado de la sentencia definitiva, se requería de la comprobación del cuerpo del delito, pues el estándar de la orden de aprehensión era mínimo, ya que bastaba la existencia de un hecho determinado susceptible de ser delito. Otro dato importante que destaca el propio autor, es que: “(...) la Ley Orgánica del Artículo 103 de la Constitución de 1857, que para dictar una orden de aprehensión exigía la comprobación del cuerpo del delito, ya no puede ser aplicada por encontrarse derogada (...)". ${ }^{50}$

Así, con independencia de que si esa exigencia redundaba o no en el dictado de la orden de aprehensión, es patente que al menos, desde el siglo XIX, al aludirse en la normatividad, al cuerpo del delito, hay evidencia de la tendencia causalista en México en esa época.

Y la SCJN, ante la indefinición normativa del concepto del cuerpo del delito, su jurisprudencia tuvo que acotarlo, estimando que por aquel

49 PENICHE LÓPEZ Vicente, op. cit., p. 272.

s0 Ibidem, p. 273. 
debía entenderse: “(...) el conjunto de elementos objetivos externos que constituyen el delito, con total abstracción de la voluntad o del dolo (...)”. ${ }^{11}$

\subsection{Segunda Época. Finalismo (1993-1999).}

Es hasta el 4 de septiembre de 1993, que entró en vigor el decreto que reformó los artículos 16, 19, 20 y 119 de la CPEUM, y de dichas reformas es digno de resaltar que se sustituyó la tendencia causalista denotada, al apartarse de la noción de "cuerpo del delito", por el concepto finalista de "elementos del tipo", ya que para librar una orden de aprehensión, o decretar un auto de formal prisión era necesario -además de otros requisitos de procedibilidad-, la existencia de datos que hicieran probable la responsabilidad del acusado y acreditaran los elementos del tipo penal.

Tipo delictivo y corpus delicti, son conceptos relacionados íntimamente; el primero se refiere a la conducta, considerada antijurídica por el legislador; y el segundo, a la realización del delito; en consecuencia, para que exista el cuerpo de un delito determinado, deberá contarse con el tipo delictivo correspondiente. ${ }^{52}$

Aun cuando la expresión de "tipo" ha sido utilizada en sentidos muy diversos, dogmáticamente el tipo penal es, ante todo, tipo de injusto, esto es, delimitación de las características determinantes del injusto específico de cada figura delictiva. ${ }^{53}$

El tipo legal se presenta, en ocasiones, como mera descripción de conducta, en otras, alude al resultado material, o bien, hace referencia a calidades determinadas en los sujetos, o a los medios de comisión, o a las modalidades de la conducta; puede hacer referencia, en fin, a estados de ánimo, finalidades de la acción, tendencias del sujeto, etc., de

51 Tesis sin número, Semanario Judicial de la Federación, Quinta Época, Tomo CIII, p. 1897, núm. de registro 300352, rubro: "Cuerpo del delito.”.

52 COLÍN SÁNCHEZ, Guillermo, op. cit., p. 377

53 COBO DEL ROSAL, Manuel; VIVES ANTÓN, Tomás S., Derecho Penal, Parte General. 5a. Ed. corregida, aumentada y actualizada. Valencia: Tirant lo Blanch, Valencia, 1999, p. 306. 
ahí la necesidad de clasificar los distintos elementos de que puede estar compuesto el tipo penal.

A partir de las citadas reformas a nuestra Carta Magna, los juzgadores quedaron obligados a precisar en sus resoluciones, relativas a órdenes de aprehensión, autos de formal prisión y sin duda sentencias, que se habían comprobado estos elementos del tipo penal.

Como consecuencia de lo anterior, los códigos penales y de procedimientos penales federales, cuyas reformas entraron en vigor a partir de $1^{\circ}$ de febrero de 1994 , también hacían referencia constante a los elementos del tipo penal.

El Causalismo y el Finalismo son parte de la evolución progresiva e infinita del derecho, son manifestaciones perfectibles de la obra humana, estos sistemas ya son escalones de otros. La meta, un derecho perfecto, que no por ser inalcanzable, deja de ser faro que ilumina el camino del hombre y del penalista en particular. ${ }^{54}$

Estas reformas constituyeron un paso adelante en la evolución de la teoría del delito en México, subiendo un escalón más hacia un derecho penal más justo, apoyado en la moderna Criminología, que participe de una imagen compleja del suceso delictivo de acuerdo con el rol activo y dinámico que atribuye a los protagonistas del mismo (delincuente, víctima, comunidad) y la relevancia acusada de los muy diversos factores que convergen e interactúan en el "escenario" criminal.

Sin embargo, nuestro derecho regresó al punto de partida del Causalismo, como se expone en las líneas siguientes.

\subsection{Tercera Época. Causalismo "afinalizado" (1999-2008).}

El 8 de marzo de 1999 se publicó nuevamente otra reforma a los artículos 16 y 19 de la CPEUM. La iniciativa del Ejecutivo de la Nación que culminó en las recientes reformas señaló en su exposición de motivos -entre otros muchos-, los siguientes:

a) La reforma de 1993 al artículo 16 consideró teorías y escuelas de otras naciones que no corresponden al desarrollo del

54 ORELLANA WIARCO, Octavio Alberto, op. cit., p. 206 
Derecho Penal Mexicano, al exigirse acreditar los elementos del tipo penal como uno de los requisitos para librar una orden de aprehensión.

b) Después de 4 años de aplicarse la reforma de 1993 se ha observado que por "tecnicismos legales", presuntos delincuentes evaden la acción de la justicia, y en 1997 de todas las averiguaciones consignadas a la autoridad judicial, sólo se obsequiaron el 20\% de ellas, debido al grado excesivo de "exigencia probatoria" impuesta al Ministerio Público, lo que ha provocado mayor delincuencia e impunidad.

La reforma aludida, fue objeto de análisis en consulta con grupos sociales, y al parecer se mostró rechazo por parte del Foro Nacional considerando que la reforma sacrificaba la seguridad jurídica del ciudadano y favorecía al aparato de procuración de justicia que había demostrado ineficiencia en la integración de las averiguaciones. ${ }^{55}$ Es decir, la reforma suprimió en los artículos 16 y 19 el concepto de "elementos del tipo" y los sustituyó por "cuerpo del delito". Empero, no se definió en sede constitucional, qué debía entenderse por ese concepto y ello ocasionó una confusión mayúscula, porque los códigos procesales de las entidades federativas (que en aquel tiempo aun conservaban la facultad de normar leyes de procedimiento penal) y el entonces vigente Código Federal de Procedimientos Penales no pudieron definir con concreción y unidad, qué es lo que debía entenderse por "cuerpo del delito".

Si bien la tradición apuntaba en el sentido de que su contenido son "los elementos objetivos, externos o materiales apreciables por los sentidos" (más o menos como había entendido la SCJN) que se desprenden de la descripción típica; sucedió que las correspondientes legislaciones abarcaron un contenido más amplio.

En efecto, veamos el siguiente cuadro comparativo entre las legislaciones procesales federal, del Distrito Federal (ahora Ciudad de México) y del Estado de Yucatán (en ese entonces en vigor):

55 Ibidem, pp.. 206-207. 


\begin{tabular}{|l|l|l|}
\hline $\begin{array}{l}\text { CÓDIGO FEDERAL DE } \\
\text { PROCEDIMIENTOS } \\
\text { PENALES }\end{array}$ & $\begin{array}{l}\text { CÓDIGO DE } \\
\text { PROCEDIMIENTOS } \\
\text { PENALES DEL D.F. }\end{array}$ & $\begin{array}{l}\text { CÓDIGO DE } \\
\text { PROCEDIMIENTOS EN } \\
\text { MATERIA PENAL DEL } \\
\text { ESTADO DE YUCATÁN }\end{array}$ \\
\hline $\begin{array}{l}\text { Art. 168.-... Por cuerpo } \\
\text { del delito se entiende el } \\
\text { conjunto de los elementos } \\
\text { objetivos o externos } \\
\text { que constituyen la } \\
\text { materialidad del hecho } \\
\text { que la ley señale como } \\
\text { delito, así como los } \\
\text { normativos, en el caso } \\
\text { que la descripción típica } \\
\text { lo requiera. }\end{array}$ & $\begin{array}{l}\text { Art. 122.- El Ministerio } \\
\text { el cuerpo del delito } \\
\text { de que se trate y la } \\
\text { probable responsabilidad } \\
\text { del indiciado, como } \\
\text { base del ejercicio de } \\
\text { la acción penal; y la } \\
\text { autoridad judicial, a } \\
\text { su vez, examinará si } \\
\text { ambos requisitos están } \\
\text { acreditados en autos. }\end{array}$ & $\begin{array}{l}\text { Art. 255. Por cuerpo } \\
\text { del delito se entiende el } \\
\text { conjunto de elementos } \\
\text { objetivos o externos que } \\
\text { constituyen la materialidad } \\
\text { del hecho que la ley señale } \\
\text { como delito, y se tendrá } \\
\text { por comprobado cuando } \\
\text { se justifique la existencia } \\
\text { de esos elementos por } \\
\text { cualquier medio de prueba } \\
\text { siempre que no sea de los } \\
\text { prohibidos por la ley. }\end{array}$ \\
\hline $\begin{array}{l}\text { El cuerpo del delito se } \\
\text { tendrá por comprobado } \\
\text { cuando se demuestre } \\
\text { la existencia de los } \\
\text { elementos que integran la } \\
\text { descripción de la conducta } \\
\text { o hecho delictuoso, según } \\
\text { lo determine la ley penal. }\end{array}$ & \\
\hline
\end{tabular}

Como puede advertirse de este cuadro comparativo, existió cierta propensión a equiparar los conceptos del "cuerpo del delito" y de "los elementos del tipo", sobre todo en la del Distrito Federal que si bien no definió lo que se entendía por "cuerpo del delito", aludió a que este se tendrá por comprobado cuando se demuestre la existencia de los elementos que integran la descripción de la conducta o hecho (todos, incluidos los objetivos, subjetivos y normativos), lo cual denota la comparación aludida. En cambio, tanto en la legislación federal como en la estatal, bastaba el criterio eminentemente causalista de comprobar los elementos objetivos o materiales, que son los mínimos.

Con respecto a los elementos "normativos" que incluye en su fórmula del corpus delicti la ley adjetiva federal, cabe mencionar que 
González Quintanilla ${ }^{56}$ opina que “(...) el tipo se desglosa en elementos objetivos (entre los que se encuentran los normativos) y elementos subjetivos (...)".

Por su parte, con respecto a los "elementos normativos", Díaz y García Conlledo ${ }^{57}$, niega su existencia en estos términos:

“(...) lo principal es que, ni éstas ni otras definiciones, como las que desde la Filosofía analítica del lenguaje, distinguen entre hechos naturales y hechos institucionales o por la referencia a cualidades naturales y cualidades convencionales, satisfacen plenamente; las nuevas definiciones en realidad son reformulaciones, según creo, de la idea de la referencia a normas. Pero ninguna convence plenamente, porque en realidad no existen -o no existen apenas- elementos descriptivos o normativos puros, sino que los elementos típicos tienen componentes de ambas clases; piénsese en el tantas veces citado por la doctrina ejemplo de elemento "persona" u "otro" en el homicidio, que parece claramente descriptivo, pero sin embargo se carga de tintes normativos en tanto se plantean los límites de la vida humana (comienzo y fin), por ello, desde antiguo hay autores que propugnan incluso el abandono de la distinción (...)".

De aquí se ve que no existió consenso sobre cuáles serían los elementos normativos, y ante tal circunstancia el problema se acrecentó, dado que hoy por hoy la doctrina no puede definir siquiera a los conceptos mínimos de los elementos objetivos del delito y la legislación positiva no orientó al respecto, de modo que su delimitación residió en última instancia a criterio de los tribunales federales encargados del control constitucional.

El dilema que se plantea en adoptar determinado contenido para el concepto "cuerpo del delito" radica, a nuestro modo de ver, entre la seguridad de la protección de la garantía de libertad para el individuo y

56 GONZÁlEZ QUINTANILLA, José Arturo. Derecho Penal Mexicano. Parte General y Parte Especial. Metodología Jurídica y desglose de las constantes, elementos y configuración de los tipos penales. México: Porrúa, 1996, p. 275

DÍAZ Y GARCÍA CONLLEDO, Miguel. Los elementos normativos del tipo penal y la teoría del error. En: LUZÓN PENA, Diego-Manuel; MIR PUIG, Santiago (comps.). Cuestiones actuales de la Teoría del Delito. Madrid: Mc-Graw Hill, 1999, p. 65. 
la seguridad de la protección a la sociedad de las conductas que dañan o ponen en peligro bienes jurídicos. Es decir, si se opta por asignar al "cuerpo del delito" el tradicional contenido referido a "elementos objetivos o materiales" se pone en riesgo la garantía de libertad; si elegimos otorgar al "cuerpo del delito" la suma de los elementos objetivos, subjetivos y normativos ello redundará en mayor seguridad jurídica a quien se le impute la comisión de un delito; pero ello obligará a un mayor esfuerzo del aparato de procuración de justicia de allegarse los elementos probatorios que acrediten los elementos del tipo ${ }^{58}$.

En ese sentido, la reforma constitucional de 1999, a fin de no ser retrógrada se consideró bajo la óptica de que el "nuevo" cuerpo del delito -aunque se escuche como una aseveración impropia- tuviese una perspectiva finalista, es decir, asignándosele un contenido más amplio al referido hace más de 150 años que incluía únicamente a elementos materiales u objetivos, dado que de quedarse las cosas como se encontraban -sobre todo en nuestro Estado de Yucatán- nos veríamos frente a un estado totalitario.

También, aceptar como contenido del "cuerpo del delito" únicamente a los elementos objetivos o materiales previstos en el tipo llevaría a plantear los problemas de la tentativa, de los elementos subjetivos del tipo y del injusto, de la responsabilidad objetiva, etc., que el finalismo ya había superado.

Por esa razón, el Poder Judicial de la Federación emitió variada jurisprudencia al respecto, llegando a la conclusión de que, en México, la sistemática penal que imperaba en ese momento histórico, era ecléctica, pues si bien el ordenamiento constitucional aludía al concepto de "cuerpo del delito", la normatividad secundaria presentaba tintes finalistas. ${ }^{59}$

58 RIVERO EVIA, Jorge. La teoría del delito en la Constitución mexicana. EN: Ávila Heredia, Ricardo de Jesús (Coordinador), Centenario 1917-2017. Constitución Política de los Estados Unidos Mexicanos, Mérida: Poder Judicial del Estado de Yucatán, 2017, p. 107.

59 Muestra de ello es la tesis pronunciada por el entonces, el Tercer Tribunal Colegiado del XIV Circuito, de rubro: "Modificativas y calificativas. Deben incluirse en el dictado de una orden de aprehensión y de una formal prisión, a la luz de la reforma de treinta de marzo de dos mil a los códigos penal y de procedimientos en materia penal del Estado de Yucatán.”. Tesis XIV.3o.7 P 


\subsection{Cuarta Época. Sistema acusatorio (2008- fecha ACtual).}

La CPEUM volvió a ser reformada mediante decreto publicado en el Diario Oficial de la Federación el 18 de junio de $2008,{ }^{60}$ a fin de sentar las bases de un proceso penal radicalmente diverso al que se venía practicando en la nación.

El nuevo paradigma, denominado "acusatorio" presenta notas muy peculiares que transforma el ámbito competencial de las autoridades judiciales, así como la estructura de la averiguación previa (la que desaparece como tal), del proceso (con la inclusión de jueces de control y tribunales de juicio oral) y de la ejecución de las sanciones (contando con jueces de ejecución).

Asimismo, entre otras cosas destaca la nueva concepción constitucional de los componentes de dos de las resoluciones más importantes en el proceso penal que dictará el Juez de Control (diverso a la autoridad que determinará la culpabilidad, denominada Tribunal de juicio oral o de enjuiciamiento); a saber, la orden de aprehensión y el auto de vinculación a proceso, que sustituye a la "formal prisión". ${ }^{61}$

Semanario Judicial de la Federación y su Gaceta, Novena Época, t. XVI, julio de 2002, p. 1336, núm. de registro: 186521.

${ }^{60}$ Conforme a los artículos transitorios respectivos, el nuevo sistema de justicia, entraría gradual y paulatinamente en vigor en el Estado Mexicano, teniendo como fecha límite el 2016 para que abarcara a todo el territorio nacional. En esos 8 años de derrotero, la gran mayoría de las Entidades Federativas emitieron sus propios códigos procesales penales y otro tipo de leyes afines. No obstante, en ese periodo que podemos llamarle de "calibración”, la Federación se irrogó la facultad exclusiva de legislar en materia procesal penal. Ello dio como resultado, en 2013, la expedición del Código Nacional de Procedimientos Penales, que es un código único en materia adjetiva penal.

61 El auto de formal prisión en los procedimientos tradicionales y el auto de vinculación a proceso en el sistema acusatorio son de naturaleza y efectos distintos, pues el primero no tiene sentido y sustento bajo el nuevo sistema de enjuiciamiento oral, de corte garantista, en el que los imputados deberán ser considerados inocentes, hasta que se dicte sentencia firme en su contra, además, cuenta con nuevas reglas procesales, ya que para dictar un auto de vinculación a proceso únicamente se requiere que los datos (no pruebas formalizadas) que fueron recabados en la carpeta de investigación establezcan el delito que se atribuye al imputado, el lugar, tiempo y las circunstancias de ejecución, y que exista la probabilidad de que él lo cometió o participó en su comisión; incluso se sustituyó la determinación de resolver sobre la libertad 
En su actual redacción, el párrafo tercero del artículo 16 de la CPEUM, ordena:

(...) No podrá librarse orden de aprehensión sino por la autoridad judicial y sin que preceda denuncia o querella de un hecho que la ley señale como delito, sancionado con pena privativa de libertad y obren datos que establezcan que se ha cometido ese hecho y que exista la probabilidad de que el indiciado lo cometió o participó en su comisión (...).

Por su parte, el artículo 19 de la misma Constitución establece:

(...) Ninguna detención ante autoridad judicial podrá exceder del plazo de setenta y dos horas, a partir de que el indiciado sea puesto a su disposición, sin que se justifique con un auto de vinculación a proceso en el que se expresará: el delito que se impute al acusado; el lugar, tiempo y circunstancias de ejecución, así como los datos que establezcan que se ha cometido un hecho que la ley señale como delito y que exista la probabilidad de que el indiciado lo cometió o participó en su comisión (...).

En efecto, en el tema que interesa, llama la atención la sustitución de los conceptos "cuerpo del delito" y "probable responsabilidad" por los diversos de "hecho" y "probabilidad de comisión o participación”.

Se dispone en la CPEUM que los puntos cardinales tanto de la orden de aprehensión, como del auto de vinculación a proceso sean: - El hecho en sí mismo; y - La probabilidad de que el indiciado lo cometió o participó en su comisión. Todo ello con base en "datos".

O sea, se ha vuelto a modificar el título de la imputación, prescindiendo de elementos de la teoría del delito, y aludiendo a cuestiones fácticas.

del imputado, pues eso, en su caso, será motivo de una medida cautelar, la que de manera independiente deberá solicitar la autoridad investigadora de los delitos; además, el Juez sólo puede decretar la prisión preventiva a petición del Ministerio Público cuando otras medidas cautelares no sean suficientes para garantizar la comparecencia del imputado en el juicio, el desarrollo de la investigación, la protección de la víctima, de los testigos o de la comunidad, así como cuando el imputado está siendo procesado o haya sido sentenciado previamente por la comisión de un delito doloso; y el Juez sólo podrá decretar la prisión preventiva de oficio, en los casos contemplados en el artículo 19 Constitucional. 
En lo atinente a la supresión del corpus delicti, por el concepto de hecho ${ }^{62}$, debe decirse que ello guarda congruencia con la acepción constitucional que la Primera Sala de la $\mathrm{SCJN}^{63}$, le ha dado a la palabra delito: “(...) la palabra 'delito', en el citado precepto constitucional (el 19), no significa la clasificación jurídica que de los hechos atribuidos al procesado hace la ley, sino el conjunto de actos que integran el hecho criminoso y que, por ser perjudiciales a la sociedad, son reprimidos y castigados por la autoridad pública (...)".

A su vez, el CNPP ${ }^{64}$ desarrolla dicho nuevo título de imputación penal, en los siguientes términos:

a. En tratándose de la emisión del citatorio, orden de comparecencia o de aprehensión. (Artículo 141), se exige:

- Denuncia o querella de un hecho que la ley señale como delito.

- Elaboración por parte del Ministerio Público de una carpeta de investigación.

- Anuncio del Ministerio Público al Juez de Control de la existencia en esa carpeta de investigación, de datos que establezcan que se ha cometido ese hecho y haya la probabilidad de que el imputado lo hubiese cometido o participado en su comisión.

- Con base en ello, el Juez de Control podrá emitir; 1. Citatorio al imputado para la audiencia inicial; 2 .

${ }^{62}$ Llamémosle "hecho punible".

63 Véase ejecutoria de: MINISTERIO PÚBLICO AL INCOAR OTRA AVERIGUACIÓN POR DELITO DIVERSO AL INCULPADO ADVERTIDO CON POSTERIORIDAD AL EJERCICIO DE LA ACCIÓN PENAL, NO INFRINGE LO DISPUESTO POR EL ARTÍCULO 19 CONSTITUCIONAL. Tesis 1a./J. 15/95, Semanario Judicial de la Federación y su Gaceta, Novena Época, t. II, noviembre de 1995, p. 97, núm. de registro: 200442.

${ }^{64}$ El Código Nacional de Procedimientos Penales, obedece a la diversa reforma a la CPEUM de 8 de 9 octubre de 2013, que irrogó al Congreso de la Unión, la facultad exclusiva para legislar en materia de procedimiento penal, quedando el artículo 73, fracción XXI, de la siguiente forma: (...) El Congreso tiene facultad para expedir: (...) c) La legislación única en materia procedimental penal, de mecanismos alternativos de solución de controversias y de ejecución de penas que regirá en la República en el orden federal y en el fuero común(...). 
Orden de comparecencia, a través de la fuerza pública, en contra del imputado que habiendo sido citado previamente a una audiencia no haya comparecido, sin justificación alguna, o 3. Orden de aprehensión en contra de una persona cuando el Ministerio Público advierta que existe la necesidad de cautela.

- En la clasificación jurídica que realice el Ministerio Público se especificará el tipo penal que se atribuye, el grado de ejecución del hecho, la forma de intervención y la naturaleza dolosa o culposa de la conducta, sin perjuicio de que con posterioridad proceda la reclasificación correspondiente.

b. En cuanto al auto de vinculación a proceso (Artículo 316), las exigencias serán:

- La solicitud del Ministerio Público al Juez de control donde formule la imputación; ${ }^{65}$

- Que se haya otorgado al imputado la oportunidad para declarar;

- Que de los antecedentes de la investigación expuestos por el Ministerio Público, se desprendan datos de prueba que establezcan que se ha cometido un hecho que la ley señala como delito y que exista la probabilidad de que el imputado lo cometió o participó en su comisión. Se entenderá que obran datos que establecen que se ha cometido un hecho que la ley señale como delito cuando existan indicios razonables que así permitan suponerlo, y

- Que no se actualice una causa de extinción de la acción penal o excluyente del delito.

65 En este sistema, cabe diferenciar dos momentos claves, y diferentes en su evolución probática y argumentativa; a saber: a. La formulación de la imputación (en la audiencia inicial, ante el Juez de Control, quien con base en ella y otros datos, resolverá en su caso la vinculación a proceso o su contraria); y b. La formulación de la acusación (tras la fase de investigación complementaria -que se apertura con la vinculación a proceso-, en la audiencia intermedia, también ante el Juez de Control). 
Debe destacarse que el artículo 260 del CNPP define como "antecedente de investigación", a todo registro incorporado en la carpeta de investigación que sirve de sustento para aportar datos de prueba, y por "dato de prueba", el diverso numeral 261, entiende la referencia al contenido de un determinado medio de convicción aún no desahogado ante el Órgano jurisdiccional, que se advierta idóneo y pertinente para establecer razonablemente la existencia de un hecho delictivo y la probable participación del imputado.

Finalmente, el Tribunal de enjuiciamiento, al momento de resolver en definitiva, podrá absolver o condenar al imputado.

Si se trata de sentencia absolutoria, determinará la causa de exclusión del delito que aparezca demostrada, para lo cual podrá tomar como referencia, en su caso, las causas de atipicidad, de justificación o inculpabilidad.

El artículo 405 del CNPP refiere que son causas de atipicidad: la ausencia de voluntad o de conducta, la falta de alguno de los elementos del tipo penal, el consentimiento de la víctima que recaiga sobre algún bien jurídico disponible, el error de tipo vencible que recaiga sobre algún elemento del tipo penal que no admita, de acuerdo con el catálogo de delitos susceptibles de configurarse de forma culposa previsto en la legislación penal aplicable, así como el error de tipo invencible.

Como causas de justificación, el mismo numeral incluye al consentimiento presunto, la legítima defensa, el estado de necesidad justificante, el ejercicio de un derecho y el cumplimiento de un deber.

Y como causas de inculpabilidad distingue al error de prohibición invencible, el estado de necesidad disculpante, la inimputabilidad, y la inexigibilidad de otra conducta.

Asimismo, se faculta al Tribunal de enjuiciamiento también para tomar como referencia al error de prohibición vencible como atenuante, dejando subsistente la presencia del dolo, igual como ocurre en los casos de exceso de legítima defensa e imputabilidad disminuida.

En tratándose de sentencia condenatoria, el artículo 406 indica que solamente será emitido un pronunciamiento de esa índole, cuando exista convicción de la culpabilidad del sentenciado, bajo el principio general de que la carga de la prueba para demostrar la culpabilidad corresponde a la parte acusadora, conforme lo establezca el tipo penal de que se 
trate. Al dictarse sentencia condenatoria se indicarán los márgenes de la punibilidad del delito y quedarán plenamente acreditados los elementos de la clasificación jurídica; es decir, el tipo penal que se atribuye, el grado de la ejecución del hecho, la forma de intervención y la naturaleza dolosa o culposa de la conducta, así como el grado de lesión o puesta en riesgo del bien jurídico. Se hará referencia a los elementos objetivos, subjetivos y normativos del tipo penal correspondiente, precisando si el tipo penal se consumó o se realizó en grado de tentativa, así como la forma en que el sujeto activo haya intervenido para la realización del tipo, según se trate de alguna forma de autoría o de participación, y la naturaleza dolosa o culposa de la conducta típica. Finalmente, se argumentará por qué al sentenciado no se le favorece por ninguna de las causas de la atipicidad, justificación o inculpabilidad; igualmente, se hará referencia a las agravantes o atenuantes que hayan concurrido y a la clase de concurso de delitos si fuera el caso.

\subsection{Nota marginal. El funcionalismo en la legislación tABASQUeÑa DE ADOLESCENTES.}

Un aspecto del funcionalismo recaló en la legislación mexicana; a saber, la teoría de la imputación objetiva, que fue contemplada en la Ley que establece el Sistema integral de Justicia para Adolescentes en el Estado de Tabasco. ${ }^{66}$

En efecto, el artículo 18, fracción II, de dicho cuerpo normativo, refirió como una de las causas de atipicidad, la falta de imputación objetiva del resultado típico al comportamiento del autor, en los siguientes términos:

(...) Un comportamiento le es objetivamente imputable al autor, siempre que se pruebe que éste:

a) Creó un riesgo jurídicamente desaprobado.

b) Que dicho riesgo jurídicamente desaprobado se concretizó en un resultado típico.

66 Ya abrogada, toda vez que en la actualidad la CPEUM establece en el artículo 73, fracción XXI, inciso “c”, como facultad exclusiva del Congreso, la de emitir normatividad en materia de justicia penal para adolescentes, para regir en la República en el orden federal y en el fuero común. 
c) Que el resultado típico pertenezca al ámbito protector de la norma de que se trate.

En este sentido, la tipicidad del hecho se excluye cuando se prueba que el autor creó un riesgo jurídicamente permitido; o cuando se pruebe que la víctima, de manera auto responsable, actuó a propio riesgo, de modo que se aprecie que su comportamiento estuvo fuera del ámbito protector de la norma.

El aumento de gravedad proveniente de las circunstancias particulares de la víctima no será atribuido al autor si éste las desconocía al momento de su acción u omisión. Si el autor estuviese obligado a conocer las circunstancias particulares de la víctima que propiciaron el aumento de su gravedad, la imputación al autor será a título culposo (...).

\section{BALANCE}

Como se ha visto, a lo largo de 163 años (tomando como punto de partida 1857), México ha ido adoptando en momentos determinados teorías causalistas, finalistas o funcionalistas.

Si bien, a la presente fecha, la CPEUM no se decanta por alguna de aquellas teorías, ello no significa que la dogmática penal sea inútil en el sistema acusatorio.

En efecto, se ha destacado en las líneas anteriores, que uno de los cambios más drásticos de la reforma constitucional de 2008, en virtud de la cual se incorporó el sistema acusatorio en México, fue la eliminación del concepto de "cuerpo del delito" como requisito para librar una orden de aprehensión o emitir un auto de plazo constitucional.

La reforma penal ahora exige, para que se dicten esas dos resoluciones, requisitos concernientes al proceso y al nivel probatorio exigido en cada etapa procesal.

Los criterios que desarrolla el CNPP se relacionan con la probática necesaria en cada una de esas decisiones jurisdiccionales; así como en lo atinente al dictado de una sentencia con base en un estándar de 
prueba que trascienda más allá de toda duda razonable. Así pues, queda claro que la intención del Constituyente Permanente, fue eliminar los criterios dogmáticos prevalecientes con la frase "cuerpo del delito" y, en su momento, "elementos del tipo penal".

El otrora diseño constitucional, centraba el debate en torno a su contenido, aludiendo a criterios derivados de la teoría del delito: ¿por cuerpo del delito se entienden los elementos objetivos? ¿Se incluyen los elementos subjetivos? ¿Qué sucede con los tipos penales que incluyen elementos subjetivos como el "ánimo de dominio en el robo? ${ }^{67}$

Es cierto cuando se asevera que la prueba y sus reglas de valoración han sustituido a la teoría del delito en la Constitución Federal y que la teoría del delito ha quedado desterrada de aquella. No obstante preserva su relevancia.

La teoría del delito proporciona el camino lógico para la incriminación penal, que incluye la conformación de una conducta típica, antijurídica y culpable.

En la tipicidad se encuentran los elementos objetivos, entre los que se hallan los descriptivos y los normativos y, por último, los elementos subjetivos específicos o aquellos denominados como requeridos por el tipo penal.

Ahora bien, los elementos normativos involucran cierto tipo de valoración para su verificación que puede provenir de: i) un aspecto jurídico, en cuyo caso el juez debe considerar lo previsto en la ley para determinar el contenido y alcance del concepto en análisis; o, ii) un carácter cultural, en donde el juzgador habrá de remitirse a un aspecto social o cultural para determinar el contenido del elemento que se desea definir.

Así, el ejercicio de verificación, consistente en la delimitación del alcance y contenido de los elementos positivos (la suma de todos sus elementos) y negativos del delito (la existencia de alguna causa de exclusión del delito), se encuentran de la mano del derecho probatorio y de la argumentación jurídica básica, tanto al sostener la acusación y la

${ }^{67}$ DONDÉ MATUTE, Javier. Crítica a la teoría del delito. Bases para su destrucción (Artículo en línea). Instituto Nacional de Ciencias Penales. México. Disponible en: < http://bit.ly/2kV0Npb> Recuperado el 24 de febrero de 2017. 
defensa sus correspondientes teorías del caso, como cuando los órganos judiciales resuelven el dictado de sus sentencias.

Es decir, acorde con la teoría del delito que más le acomode, desde su perspectiva al Fiscal, al imputado, a la víctima o al juzgador, es que sus argumentos se expresarán en el enjuiciamiento.

Por tanto, al no delimitarse constitucional o legalmente como exigencia una doctrina determinada (Causalista, Finalista o Funcionalista) el operador jurídico echará mano de aquella que le convenga a sus propios intereses, lo cual, lejos de restringir la importancia de la dogmática jurídico penal, potencia su relevancia en el actual sistema y nos obliga a todos a conocer sus contenidos.

Llevando lo anterior a la parcela de la AED, la comprobación del hecho ilícito requiere la demostración de que ocurrió un evento histórico que se adecua a la descripción de alguno de los delitos previstos en el artículo 22 de la CPEUM y reflejados en la LNED, debiéndose dejar de lado el análisis a título personal de la conducta y culpabilidad como atributos de responsabilidad específica de quien lo haya cometido.

Recordemos que en la evolución del concepto "delito”, cada una de las sistemáticas penales identificó ciertos elementos. Asimismo, en un lugar común entender el concepto del delito como conducta castigada por la ley con una pena.

Así, varios elementos concurren en el delito, el cual si bien es un fenómeno unitario, que se integra de una vez y no por adición de componentes que acudan sucesivamente, es pertinente estudiarlo en cada uno de sus elementos, mediante un ejercicio de abstracción.

Es por ello, por ejemplo, que el numeral 4o., del Código Penal del Estado de Yucatán, ofrece un concepto dogmático del delito, al definirlo como "toda conducta típica, antijurídica y culpable".

De esa manera, se obtiene un concepto substancial del delito, extraído del ordenamiento penal, que acorde con la anterior fórmula, se compone de cuatro elementos: 1 . Conducta; 2 . Tipicidad; 3, Antijuridicidad; y 4. Culpabilidad.

No obstante, quien escribe estas líneas se une al criterio heptatómico, que identifica como elementos del delito, los siguientes: 1. Conducta; 2. Acción u omisión; 3. Tipicidad; 4. Antijuridicidad; 5. Imputabilidad; 6. Culpabilidad y 7. Punibilidad. 
A su vez, a cada elemento del delito, le corresponde un elemento negativo. Estos son: 1 . Ausencia de conducta; 2 . Falta de acción u omisión; 3. Atipicidad; 4. Causas de justificación; 5. Inimputabilidad; 6. Inculpabilidad y 7. Excusas absolutorias.

Por otra parte, el concepto de hecho ilícito, como se refirió previamente, se relacionó en la LFED al diverso concepto del cuerpo del delito, que acorde al artículo 168 del ya abrogado Código Federal de Procedimientos Penales, se entiendía el conjunto de los elementos objetivos o externos que constituyen la materialidad del hecho que la ley señale como delito, así como los normativos, en el caso que la descripción típica lo requiera.

De acuerdo con esa definición de hecho ilícito en términos de cuerpo del delito, una primera interpretación podría ser que los elementos de los tipos penales de delincuencia organizada, contra la salud y los demás propios de la AED que deben probarse, solo son aquellos que tengan la naturaleza de objetivos o normativos, no así los que sean subjetivos ${ }^{68}$.

Ello no sería lo correcto, puesto que, por certeza jurídica, tales componentes del elemento del delito denominado tipicidad, deben ser demostrados en su totalidad tanto en el ámbito penal como en el de la extinción de dominio. De ahí que en líneas precedentes se expresó que en nuestro país se tuvo un periodo de un cuerpo del delito afinalizado que mezcló ideas de la sistemática Causalista y de la Finalista (1999-2008).

Sin embargo, la LNED ya no alude al cuerpo del delito, pues al definir hecho ilícito en la fracción XII del artículo 2, indica que por éste entiende el conjunto de conductas a que se refiere el párrafo cuarto del artículo 22 de la Constitución y se precisan en el artículo 1 de la propia ley. Por ende, solo refiere a descripciones típicas.

68 Los elementos objetivos son los que pueden percibirse por los sentidos. Los subjetivos, en cambio, son motivaciones o fines de una persona, es decir, se ubican en la mente del sujeto, de forma que no pueden percibirse sensorialmente. Los normativos son elementos introducidos en el tipo por el legislador, que aluden a una valoración jurídica o cultural. Véase: COTA MURILLO, Saúl; ORDUÑA SOSA, Héctor. Análisis de los elementos constitucionales y legales de la extinción de dominio (artículos 22 constitucional y 2, 8 y 54 de la Ley Federal de Extinción de Dominio), en MARROQUÍN ZALETA, Jaime, op. cit., p. 74. 
Lo anterior permite aseverar que el juicio respecto del hecho ilícito en la AED, no versará en torno al delito compuesto de los siete elementos antedichos, sino que quederá en un mero análisis de tipicidad, donde en su demostración sí se requerirá de la existencia de los elementos objetivos, subjetivos y en su caso normativos que el tipo penal correspondiente describa y por tanto, exija. Es decir, es fehaciente el retorno al cuerpo del delito. Un cuerpo del delito "afinalizado".

Un ejemplo de esto puede ser en el caso de la delincuencia organizada: un elemento objetivo, perceptible sensorialmente, será que tres o más personas estén organizadas; un elemento subjetivo, será que ese grupo tenga como finalidad realizar, en forma permanente o reiterada conductuas cuyo objetivo sea cometer uno de los delitos señalados en el artículo 2 de la Ley Federal contra la delincuencia organizada, como es el caso de delitos contra la salud (posesión de narcótico con fines de venta); y un elemento normativo lo constituye el concepto de "narcótico", que habrá que atender a la definicióm que contempla la Ley General de Salud.

Entonces, se insiste en que de los siete elementos del delito, solamente la tipicidad será materia de prueba en la AED.

En ese sentido, es factible dejar de analizar causas de justificación, excluyentes o eximentes de delito a título personal, ya que para eso está el procedimiento penal.

Clarifiquemos lo anterior.

La consecuencia legal directa de cualquier circunstancia eximente es la exclusión de un pronunciamiento de condena penal respecto del sujeto en el que concurre, derivado de la inimputabilidad, como elemento negativo del delito o de la inculpabilidad ${ }^{69}$. Asimismo, puede existir la

69 Para explicar de una manera por demás sencilla, imaginemos que el delito es como una moneda al aire, cuando cae, lo hace de un lado, (águila o sol); lo mismo es en cuanto al delito, hay un aspecto positivo y uno negativo. Parte de la doctrina, suele identificar como elementos positivos del delito a los siguientes: 1 . Conducta; 2 . Acción u omisión; 3. Tipicidad; 4. Antijuridicidad; 5. Imputabilidad; 6. Culpabilidad y 7. Punibilidad. Ahora, dichos elementos tienen que darse de manera conjunta y en una prelación lógica, para que exista delito. El otro lado de la moneda, se constituye con los elementos negativos del delito, es decir, a cada elemento positivo, le correspondería uno negativo. A diferencia de los elementos positivos, los que deben existir de manera unitaria para que se dé el injusto, con que en un hecho se acredite la existencia de 
inimputabilidad disminuida, pues existen casos en donde las circunstancias excluyentes se presentan sin reunir todos los elementos necesarios para su plena eficacia, o con una intensidad menor.

En atención a ello, la doctrina suele clasificar a las eximentes en dos especies: completas e incompletas.

Una circunstancia eximente completa hace referencia a un conjunto de factores o situaciones que, por exigencias legales, tienen la virtualidad de eximir totalmente de la responsabilidad penal del sujeto que ha perpetrado una infracción penal, aun cuando el hecho pueda acarrear por el agente otro tipo de consecuencias jurídicas (medidas de seguridad, responsabilidad civil, etc. $)^{70}$.

En cambio, las eximentes incompletas, son vistas como atenuantes. Según Borja Jiménez ${ }^{71}$, son tres los componentes del concepto de eximente incompleta; a saber:

- El elemento formal, que se obtiene de la definición que la regla expresa de derecho refleja en la Ley.

- El componente material cuantitativo, que se constituye por un presupuesto positivo y otro negativo. Para apreciar una

uno de los negativos, bastará para que el delito no subsista o se excluya. Así, los multicitados elementos negativos son: 1 . Ausencia de conducta humana; 2. Falta de acción u omisión; 3. Atipicidad; 4.Causas de justificación; 5. Inimputabilidad; 6. Inculpabilidad y 7. Excusas absolutorias. En lo que aquí interesa-eximentes en crímenes competencia de la CPI-, podemos sostener la misma idea, específicamente en relación a la imputabilidad-inimputabilidad. Una conducta que revista los caracteres exteriores de delito no entra dentro de la esfera del Derecho Penal, sino en cuanto lo que una persona haya realizado exteriormente, se halle ligado con una disposición de su voluntad no armonizable con las exigencias del Derecho. Conceptualmente, la imputabilidad es la capacidad de autodeterminación del ser humano para actuar conforme con el sentido, teniendo la facultad de comprender la antijuridicidad de su conducta. Por ende, será imputable aquel individuo que es libre para pensar, para hacer y que comprende la finalidad de sus actos, motivándose por la norma. Son imputables pues, quienes cuentan con capacidad no solo jurídica, sino natural, quienes no se encuentren privados de sus facultades mentales. Así, la inimputabilidad es el aspecto negativo de la imputabilidad, o sea, es la incapacidad para entender y querer en materia penal. BORJA JIMÉNEZ, Emiliano. Las circunstancias atenuantes en el ordenamiento jurídico español, Valencia: Tirant lo Blanch, 2002, p. 16.

71 Ibidem., pp.17-18. 
eximente incompleta, es menester que concurra el requisito esencial que fundamenta la razón de ser de cada causal; por ejemplo, la agresión ilegítima en la legítima defensa o la situación de necesidad (conflicto real de bienes jurídicos en el estado de necesidad. El presupuesto negativo implica que no debe concurrir en el hecho alguno de los requisitos considerados como no esenciales; por ejemplo, puede estar ausente la necesidad racional en el medio empleado para repeler la agresión o la intención de actuar con la finalidad de tutelar un bien jurídico de mayor o igual relevancia que el que se lesiona.

- El elemento material punitivo. Alude a la capacidad atenuatoria que se constituye en la consecuencia más relevante; actúa sobre la clase de pena y no sobre la cuantía de la pena (determinando una rebaja de sanción).

Con vista en lo anterior, $\dot{i}$ si tales circunstancias eximen de la responsabilidad criminal se les podrá encuadrar en la litis de la acción de extinción de dominio?

La respuesta es un rotundo no, dado que el elemento denominado "hecho ilícito" únicamente requiere de los elementos objetivos que constituyen su materialidad, con total exclusión de aquellas referencias que a título personal redunden en la imputabilidad o culpabilidad del agente.

Por ello, la AED procede aun cuando no se haya dictado la sentencia que determine la responsabilidad penal del sujeto a quien se le reprocha su comisión, pero existan elementos suficientes para determinar que el hecho ilícito sucedió.

Entonces, la noción de "cuerpo del delito" de raigambre causalista, reaparece con renovados bríos como el primer elemento de la acción de extinción de dominio.

\section{Conclusiones}

Primera. Los conceptos "delito" y "hecho ilícito", para efectos de la AED, no son sinónimos, puesto que aquél se constituye con una conjunción 
de siete elementos: (1. Conducta; 2. Acción u omisión; 3. Tipicidad; 4. Antijuridicidad; 5. Imputabilidad; 6. Culpabilidad y 7. Punibilidad); en tanto que el "hecho ilícito", se circunscribe a la mera descripción típica.

Segunda. Esa descripción típica se erige en el elemento del delito denominado "tipicidad", que abarca a su vez, en atención de la fórmula gramatical que el legislador disponga, en su caso, otros elementos componentes; a saber: elementos objetivos, subjetivos o normativos.

Tercera. Si bien tanto la CPEUM como la LNED, ya no aluden al concepto del "cuerpo del delito", se denota que, aun esa entelequia se vincula al diverso concepto de "hecho ilícito".

Cuarta. Lo anterior en virtud de que si por "hecho ilícito" comprendemos "descripción típica", ello nos conduce a un solo elemento que reduce el standart probatorio en la AED, es decir, la "tipicidad", que en su caso, comprende la demostración únicamente de los elementos objetivos, normativos y subjetivos que gramaticalmente el legislador ha diseñado al crear el injusto penal, y de ahí su independencia para con el proceso penal, en donde si se habrá de demostrar el delito en su totaldad. De tal forma que en la AED no será materia de análisis los denominados "elementos negativos del delito" o eximentes, sino únicamente, la "atipicidad".

Quinta. Todo ello nos lleva a concluir que se experimenta un retorno a la noción del "cuerpo del delito" que al incluir los elementos subjetivos de la descripción típica, se inclina hacia un "cuerpo del delito afinalizado”, que imperó en México en el periodo de 1999 a 2008.

\section{REFERENCIAS}

ÁLVAREZ DE LARA, Rosa María; BRENA SESMA, Ingrid; GONZÁLEZ ALCÁNTARA, Juan Luis (coords.). Diccionario de derecho civil y de familia. México: Porrúa, 2004.

ÁVILA HEREDIA, Ricardo de Jesús (Coordinador), Centenario 1917-2017. Constitución Política de los Estados Unidos Mexicanos, Mérida: Poder Judicial del Estado de Yucatán, 2017.

BERISTÁIN IPIÑA, Antonio. Victimología. Nueve palabras clave. Valencia: Tirant Lo Blanch, 2000. 
BORJA JIMÉNEZ, Emiliano. Las circunstancias atenuantes en el ordenamiento jurídico español, Valencia: Tirant lo Blanch, 2002.

CARBONELL, Miguel. Los derechos fundamentales en México. México: Porrúa, 2005. CARBONELL, Miguel; CRUZ BARNEY, Óscar; PÉREZ PORTILLA, Karla (comps.). Constituciones históricas de México. México: Porrúa, 2004.

CASTRO, Juventino V. Garantías y Amparo. México: Porrúa, 2000.

COBO DEL ROSAL, Manuel; VIVES ANTÓN, Tomás S., Derecho Penal, Parte General. 5a. Ed. corregida, aumentada y actualizada. Valencia: Tirant lo Blanch, Valencia, 1999.

COLÍN SÁNCHEZ, Guillermo. Derecho mexicano de procedimientos penales. México: Porrúa, 1997.

COSSÍO DÍAZ José Ramón (coord.). Constitución Política de los Estados Unidos Mexicanos Comentada. México: Tirant lo Blanch, 2017.

DÍAZ DE LEÓN, Marco Antonio. Historia del derecho penal y procesal penal mexicanos. T. I. México: Porrúa, 2005.

DONDÉ MATUTE, Javier. Crítica a la teoría del delito. Bases para su destrucción (Artículo en línea). Instituto Nacional de Ciencias Penales. México. Disponible en: < http://bit.ly/2kV0Npb> Recuperado el 24 de febrero de 2017.

FRAGA, Gabino. Derecho Administrativo. México: Porrúa, 1991.

GONZÁLEZ QUINTANILLA, José Arturo. Derecho Penal Mexicano. Parte General y Parte Especial. Metodología Jurídica y desglose de las constantes, elementos y configuración de los tipos penales. México: Porrúa, 1996.

GUTIÉRREZ-ALVIZ Y ARMARIO, Faustino. Diccionario de derecho romano. Madrid: Reus, 1982.

JESCHECK, Hans-Heinrich. Tratado de Derecho Penal (Parte General), $4^{\mathrm{a}}$. Ed. Granada: Comares, 1993.

LUZÓN PEÑA. Diego-Manuel; MIR PUIG, Santiago. Cuestiones actuales de la Teoría del Delito (comps.). Madrid: McGraw Hill, 1999.

MARROQUÍN ZALETA, Jaime Manuel (Coordinador), Extinción de dominio, México: Instituto de la Judicatura Federal-Porrúa, 2009.

MUÑOZ CONDE, Francisco. Teoría general del delito. Valencia, Tirant lo Blanch, 1989. 
NIETZSCHE, Friedrich. Aurora. Biblioteca conmemorativa Nietzsche. Aurora, El Anticristo, Edición Editorial Libsa, Madrid, 2000; Coedición Edivisión, Compañía Editorial S.A.

ORELLANA WIARCO, Octavio Alberto, Teoría del delito. Sistemas Causalista, Finalista y Funcionalista. Teoría del delito y Teoría del Caso. México: Porrúa, 2020 PALOMAR DE MIGUEL, Juan. Diccionario para juristas. México: Porrúa, Tomo I (A-I), 2008.

PENICHE LÓPEZ, Vicente. Garantías y Amparo. México: Suprema Corte de Justicia de la Nación- Benemérita Universidad Autónoma de Puebla, 2007.

PLASCENCIA VILLANUEVA, Raúl. Teoría del delito. Serie G: Estudios doctrinales, núm. 192. México: UNAM- Instituto de Investigaciones Jurídicas, 1998.

QUINTINO ZEPEDA, Rubén. La ciencia del derecho penal a través de sus autores. México, Flores Editores, 2009.

ROXIN, Claus. Derecho Penal. Parte General. Tomo I. Fundamentos, la estructura de la teoría del delito. Madrid: Civitas, 1999.

RIVERO EVIA, Jorge. “A propósito de la teoría del delito: ¿Es aún necesaria en el sistema acusatorio mexicano?”. Revista In Iure Anáhuac Mayab, año 5, núm 10, 2017.

VIVES ANTÓN, Tomás S. Fundamentos del sistema penal. Valencia: Tirant lo Blanch, 1996.

VON LISZT, Franz. Tratado de derecho penal. Buenos Aires: Valetta Ediciones, 2007.

WELZEL, Hans. Estudios de derecho penal. Buenos Aires: B de F, 2002. 


\section{Informações adicionais e declarações dos autores (integridade científica)}

Declaração de conflito de interesses (conflict of interest declaration): o autor confirma que não há conflitos de interesse na realização das pesquisas expostas e na redação deste artigo.

Declaração de autoria e especificação das contribuições (declaration of authorship): todas e somente as pessoas que atendem os requisitos de autoria deste artigo estão listadas como autores; todos os coautores se responsabilizam integralmente por este trabalho em sua totalidade.

Declaração de ineditismo e originalidade (declaration of originality): o autor assegura que o texto aqui publicado não foi divulgado anteriormente em outro meio e que futura republicação somente se realizará com a indicação expressa da referência desta publicação original; também atesta que não há plágio de terceiros ou autoplágio.

Dados do processo editorial

(http://www.ibraspp.com.br/revista/index.php/RBDPP/about/editorialPolicies)

- Recebido em: 31/03/2020

- Controle preliminar e verificação de plágio: $15 / 04 / 2020$

- Avaliação 1: 20/04/2020

- Avaliação 2: 27/04/2020

- Avaliação 3: 28/04/2020

- Decisão editorial preliminar: 05/05/2020

- Retorno rodada de correções: 26/05/2020

- Decisão editorial final: 29/05/2020
Equipe editorial envolvida

- Editor-chefe: 1 (VGV)

- Editor-associado: 1 (JJEC)

- Revisores: 3 


\section{COMO CITAR ESTE ARTIGO:}

RIVERO EVIA, Jorge. La acción civil de extinción de dominio: el retorno al cuerpo del delito. Revista Brasileira de Direito Processual Penal, Porto Alegre, vol. 6, n. 2, p. 617-666, mai./ago. 2020. https://doi.org/10.22197/rbdpp.v6i2.357

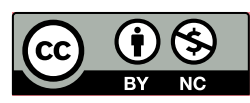

Esta obra está licenciada com uma Licença Creative Commons Atribuição-NãoComercial 4.0 Internacional. 